\title{
DART mass spectrometry as a potential tool for the differentiation of captive-bred and wild lion bones
}

\author{
Peter Coals ${ }^{1,2}$ (D) Andrew Loveridge ${ }^{1}$. Dominic Kurian ${ }^{3} \cdot$ Vivienne L. Williams $^{1,2}$. \\ David W. Macdonald ${ }^{1} \cdot$ Rob Ogden ${ }^{3,4}$
}

Received: 30 June 2020 / Revised: 11 December 2020 / Accepted: 26 March 2021 / Published online: 13 April 2021 (c) The Author(s) 2021

\begin{abstract}
In recent years lion bones have been legally traded internationally to Asian markets from captive-bred sources in South Africa. There are also indications of increasing instances of illegal international trade in wild lion bones. The existence of parallel captive and wild supplies of lion bone are a cause of law enforcement concern regarding the potential for the laundering of illegally sourced bones through legal trade, and present a problem for the assessment of the conservation impact of wild lion bone trade due to the difficulty of determining what market-share wild and captive-bred lion bones account for. Captive-bred and wild lion bone are visually indistinguishable and no reliable method currently exists for distinguishing them. We present a preliminary study that explores the use of DART mass spectrometry as a method to differentiate between captive-bred and wild lion bones. We find that DART is able to differentiate between a batch of captive-bred South African lion bone and a batch of wild lion bone and suggest that DART mass spectrometry shows strong potential as a tool for the regulation and investigation of lion bone trade. Further testing is needed to prove the suitability of this technique. Therefore, we suggest that further research focuses on testing the capability of DART to differentiate between contemporary wild and captive-bred lion bone originating from South Africa, and attempts to identify chemical markers in bone that can be used as indicators of captive-bred origin.
\end{abstract}

Keywords Conservation · Wildlife trade IWT $\cdot$ Regulation · Law enforcement · Forensics $\cdot$ Panthera leo

Communicated by Stephen Garnett.

Peter Coals

peter.coals@outlook.com

Rob Ogden

Rob.Ogden@ed.ac.uk

Extended author information available on the last page of the article 


\section{Introduction}

Wildlife trade is a multi-billion dollar industry that encompasses a great variety of organisms across a broad range of uses, and occurs in both legal and illegal guises (Broad et al. 2014). The overexploitation of wildlife for trade purposes can have severe impacts on species conservation (Hemley 1994) and the unregulated, illegal trade in wildlife is believed to be amongst the largest illegal industries in the world with significant links to corruption, violence, subversion of development and social stability, and the spread of zoonotic diseases of global health concern (Zimmerman 2003; Warchol 2004; Macdonald and Laurenson 2006; Rosen and Smith 2010; UN 2018; Gore et al. 2019; Volpato et al. 2020).

Sustainable wildlife trade, typically from farmed or ranched sources, has been suggested as a means to reduce the prevalence and negative impacts of illegal wildlife trade-through the reduction of financial incentives for illegal trade, whilst maintaining positive livelihood contributions of legal trade (Bulte and Damania 2005; Damania and Bulte 2007). However, the simultaneous existence of both legal and illegal supplies of wildlife products has led to concern regarding the potential for laundering of products from illegal sources into legal markets and thus negatively impacting wild populations (Fischer 2004; Lyons and Natusch 2011; Jimenez-Bustamante and Rentería 2018). In addition to conservation-based concerns there are also wider societal concerns regarding the facilitation of transnational organised crime by wildlife markets (Warchol 2004; van Uhm 2018). Supply-side approaches to reduction of wildlife exploitation thus require means to verify authenticity and thereby reduce possibilities for criminal activity (i.e. smuggling and laundering) in order to be successful (Damania and Bulte 2007). The trade in lion (Panthera leo) bones and body parts exemplifies such concerns.

In the wild, lions are classified as vulnerable, having disappeared from $~ 92 \%$ of their historic range and declined by 43\% during the two decades between 1993 and 2014, leaving an estimated 23,000-39,000 individuals living in the wild (Bauer et al. 2016). In addition to established threats (see Bauer et al. 2015) the illegal trade in wild lion parts is believed to be increasing and concerns have been raised that associated poaching may become a threat to wild lion populations (Williams et al. 2017a; Everatt et al. 2019). Increasingly, instances of seizures of illegal lion products linked to intercontinental trade are reported, especially to East and Southeast Asia (e.g. EAGLE 2017, 2018; Everatt et al. 2019).

In South Africa there are more than 300 registered facilities for breeding and rearing at least 7800 lions, as indicated on Threatened or Protected Species (ToPS) permits for South Africa, a number which excludes keeping-only facilities-the inclusion of which is likely to increase the estimated number of facilities to over 400, however absolute numbers are not known (Williams et al. 2015; Williams and 't Sas-Rolfes 2019). The international commercial trade in the skeletons (bones, teeth, and claws) of these captive-bred lions is permitted from South Africa under CITES Appendix II. Although in August 2019 export was placed on-hold following a domestic law judgement whereby export quotas for lion skeletons set in 2017 and 2018 were deemed to have been unlawful and unconstitutional due to an insufficient consideration of animal welfare (Republic of South Africa 2019). Nevertheless, at present there still remains the potential for future legal trade in lion skeletons. Commercial international trade in the bones and skeletal parts of wild lions is not permitted by CITES (CITES 2016). In total, over 6000 skeletons have been legally permitted for export from South Africa to Southeast Asia since 
2008, where they are believed to be used in traditional Asian medicine, health tonics, and ornaments (Williams et al. 2015).

A number of conservation, political, and socio-economic concerns have been raised surrounding the trade in lion bones and skeletons, including the influence of transnational crime (Coals et al. 2019). Organised crime groups have been linked to the legal trade in lion bones from South Africa (Williams et al. 2015) and illegal sales of lion bone and attempts to smuggle lion bones and bone products out of South Africa have been reported (e.g. Outhwaite 2018; De Telegraaf 2019). Such reports feed concern regarding the potential for laundering wild-origin lion bone through captive-bred lion bone trade both in South Africa and further down the supply chain in Asia (EIA 2017; EMS 2018).

Captive-bred and wild lion bones are indistinguishable to the naked-eye and thus present a challenge to enforcement authorities regarding the detection and prevention of laundering. In recent years South African exports of lion bone have been subject to DNA-profiling tests and physical inspections at various stages of the export process from farm to airport as required under a quota implementation protocol (DEA 2017). The purpose of these tests are primarily to detect laundering of the bones of other felid species, specifically tiger (Panthera tigris) (Dalton et al. 2018), and to ensure that multiple lion skeletons are not declared as one for export (Williams et al. 2021) but not whether skeletons initially sampled on farms came from captive-bred or wild sources. Genetic techniques can prove useful and effective for the detection of laundering of wild products into captive-bred trade (Ogden et al. 2009; Hogg et al. 2018). However, no genetic test can specifically distinguish captive-bred from wild lions (Miller et al. 2014).

Chemical elemental techniques, predominantly stable isotope and X-ray fluorescence analyses, have been used to differentiate between captive-bred or wild specimens of wildlife (Hinsley et al. 2016; Sugiyama et al. 2018; Brandis et al. 2018; He et al. 2018) but recent attempts to differentiate captive-bred and wild lion hair through carbon and nitrogen stable isotope analyses have not been conclusive (Hutchinson and Roberts 2020). However, advances in technology have significantly increased the speed and convenience of multi-compound mass spectrometry analyses through use of Direct Analysis in Real Time (DART) mass spectrometry (Cody et al. 2005a, b). DART is an ambient atmospheric ion source which produces analyte ions by reaction of ionised components of the air with the sample which may be solid, liquid, or gas. Analyte ions then pass into a mass spectrometer; the spectra produced are suitable for determination of multiple analytes and assigning tentative chemical formulas to mass peaks (Kim et al. 2010; Smoluch et al. 2016). DART mass spectrometry has proven effective for the identification of illegal substances, notably explosives and drugs (e.g. Nilles et al. 2010; Grange and Sovocool 2011), and is particularly useful in forensic and security applications where the generation of results are time-sensitive (Pavlovich et al. 2018). DART is increasingly employed in law enforcement, however, usage is not yet prevalent in wildlife forensics and wildlife crime detection. Nevertheless, it has been used to identify and differentiate between timber species in trade (Cody et al. 2012; Lancaster et al. 2012; Espinoza et al. 2014) and to identify rhinoceros horn (Price et al. 2018).

Bone incorporates metabolised chemical inputs accumulated throughout an animal's life (Meier-Augenstein 2017). Therefore, the chemical composition of bones can be used to determine animals' captive or wild provenance based on differences in chemical input (e.g. Kays and Feranec 2011). It would be expected that observable differences between captive and wild lion bones might be due primarily to diet, but could also include other inputs such as veterinary drugs and environmental chemicals such as pesticides. Wild lions have a varying diet, predominantly comprised of medium to large sized ungulates, with specific prey 
species eaten depending on the regional ungulate composition (Hayward and Kerley 2005; Davidson et al. 2013). Commercially captive-bred lions in South Africa are typically fed livestock; often mortalities from cattle farms, or other domestic animals such as chickens and donkeys, often supplemented with 'predator powder' vitamin and mineral additives (www.vtech.co.za) (pers. obs.). Commercial lion breeding and keeping facilities are often associated with agricultural and livestock-producing land, particularly in the Free State Province where the majority of commercial lion captive-breeding facilities are located (pers. obs.; Williams and 't Sas-Rolfes 2019). Although the majority of captive-bred lions' food is livestock they may also be fed commercially raised wild ungulate species-which form a large part of South Africa's commercial game meat and game hunting industries (pers. obs.). Nevertheless, in general it is assumed that predators raised in captivity tend to have more restricted diets than their wild counterparts (e.g. Kays and Feranec 2011).

We conducted a preliminary study to test whether DART mass spectrometry could potentially be used to differentiate between a batch of captive-bred and a batch of wild sourced lion bones. We expected differences in the chemical composition of lion bone batches to be identifiable with the multiple-compound spectra approach of DART mass spectrometry. We also intended to tentatively identify diagnostic compounds for any observable difference between captive-bred and wild lion bone.

\section{Method}

\section{Material}

One phalangeal bone was taken from each of 29 verified captive-bred lion skeletons from commercial breeding facilities in South Africa. Captive-bred bone samples were sourced from a commercial trader in captive-bred lion skeletons and were accessioned with the National Zoological Gardens of South Africa (Table 3 in Appendix 1). The trader sources material from a range of legal lion breeding and keeping facilities in South Africa. We understand that the material used in this study came from at least 8 different facilities. We therefore believe the captive-bred samples used in this study are representative of the type of material present in commercial lion skeleton exports. For this proof of concept study we used bone samples from the skulls of six historical museum specimens recorded to have been collected from wild lions in Anglo-Egyptian Sudan in the early twentieth century (Table 4 in Appendix 2). The choice of markedly different geographical regions, ages, and bone types between the captive and wild samples was thought to be appropriate for this test of concept because if differences were not evident from such seemingly different sample types then they were less likely to be distinguishable in contemporary wild lions from Southern Africa. A randomly selected captive-bred sample was withheld from analysis and was used as an 'unknown' sample to test validity of the classification.

\section{Sample preparation}

In order to present material of sufficient thinness and homogenous structure to the DART ion source each bone was drilled to a depth of $10 \mathrm{~mm}$ at low-medium speed (to avoid friction burning the bone) with a $3 \mathrm{~mm}$ drill-bit to create fine bone powder. The drill-bit was cleaned in between taking each sample through immersion in $99 \%$ ethanol and wiping with paper towel. Powders from each bone sample were individually suspended in $\sim 10 \mathrm{ml}$ of 
99\% ethanol which was pipette-dropped (two drops per sample) onto DART Quickstrip fine mesh grids balanced over free space so that the ethanol did not come into contact with any surface apart from the DART Quickstrip mesh. The ethanol was then allowed to evaporate from the DART Quickstrip mesh before the resulting powder, which adhered to the Quickstrip mesh, was introduced to the DART ion source using an automated rail. The 29 captive-bred samples were tested singly whilst the six wild samples were analysed in duplicate (total bones $=6$; total spectra generated $=12$ ). All samples (captive-bred and wild) were analysed at the Proteomics \& Metabolomics Facility, The Roslin Institute, University of Edinburgh, Scotland, UK on the 21st of January 2020. Following calibration of the mass spectrometer, background spectra were recorded using blank DART Quickstrip mesh directly before introduction of lion bone samples. Captive-bred samples were analysed first (using 3 DART Quickstrips consecutively) directly followed by wild samples (using 1 DART Quickstrip).

DART-MS analyses were performed on a DART-SVP ion source (IonSense Inc, Sangus, MS, USA) interfaced to a micrOTOF QII Quadrupole Time-of-Flight mass spectrometer (Bruker Daltonics, Bremen, Germany). The mass spectrometer was calibrated by infusing ESI low concentration tune mix (Agilent) prior to DART analysis. The reference tune mix included, betaine, hexamethoxyphosphazine,hexakis(2,2-difluoroethoxy)phosphazine, hexakis $(1 \mathrm{H}, 1 \mathrm{H}, 3 \mathrm{H}$-tetrafluoropropoxy)phosphazine, hexakis $(1 \mathrm{H}, 1 \mathrm{H}, 5 \mathrm{H}$-octafluoropentoxy)phosphazine, hexakis $(1 \mathrm{H}, 1 \mathrm{H}, 7 \mathrm{H}$-dodecafluoroheptoxy)phosphazine, hexakis $(1 \mathrm{H}$, $1 \mathrm{H}$, 9H-perfluorononyloxy)phosphazine, hexakis $(1 \mathrm{H}, 1 \mathrm{H}, 4 \mathrm{H}$-hexafluorobutyloxy)phosphazine, hexakis $(1 \mathrm{H}, 1 \mathrm{H}, 6 \mathrm{H}$-decafluorohexyloxy)phosphazine, hexakis $(1 \mathrm{H}, 1 \mathrm{H}, 8 \mathrm{H}$-tetradecafluorooctyloxy)phosphazine, ranging from m/z 118.0862 to 2721.8948 . Additionally, on DART source, quinine $\left([\mathrm{M}+\mathrm{H}]^{+}=325.1911\right)$ was loaded on the DART Quickstrip and spectra were collected in positive ion mode between sample data acquisition.

The optimised parameters ranges for DART were the following; helium ionization gas (99.997\%) at a flow rate of $3 \mathrm{~L} / \mathrm{min}$ with nitrogen $(99.998 \%)$ as standby gas, DART grid voltage of $600 \mathrm{~V}$, ionisation temperature of $500{ }^{\circ} \mathrm{C}$ and linear rail speed of $1 \mathrm{~mm} / \mathrm{min}$. The MS system was operated in positive-ion mode, acquiring profile MS data in a mass range of $100-1000 \mathrm{~m} / \mathrm{z}$, using oTOF control software. Collision cell energy was set at $10 \mathrm{eV}$ and quadrupole energy at $5 \mathrm{eV}$ with a PrePulse Ion storage of $10 \mu \mathrm{s}$. Data preview and integration was achieved by Compass DataAnalysis 4.2 (Bruker Daltonics, Bremen, Germany) and centroided peakslits were exported for further analysis in Mass Mountaineer.

\section{Analysis}

Analysis of DART-generated spectra was carried out using the mass spectrum elemental composition and classification software Mass Mountaineer (Mass Mountaineer Version 5.0, 2018 https://diabloanalytical.com/ms-software/mass-mountaineer/). As DART is an ambient ionisation source a background ambient spectrum was taken using DART Quickstrip mesh without bone samples. The background spectrum was subtracted from the sample spectra and the spectra were searched for common contaminants, including cleaning solutions, plastics, and products of recent decomposition (e.g. putrescine compounds), which were also removed from sample spectra. Kernel Discriminant Analysis (KDA) was used to test for separation between the sample classes of captive and wild.

KDA is an extension of Principal Component Analysis (PCA) that maps features into a higher-dimensional space using a non-linear function, and thus allows separation of points that may not be linearly separated in two-dimensions (Souza 2010). KDA is a supervised 
learning technique which uses class membership of samples in the training set in order to maximise class separation (Mass Mountaineer 2018). The ions (i.e. mass peaks) selected for the classification of captive and wild bone samples by KDA had an abundance threshold of at least $10 \%$. Classification accuracy was assessed by leave-one-out cross-validation (LOOCV) which successively omits each sample from the training set and thus compares each sample in turn against the whole of the training set (Cody et al. 2012).

Fisher's ratios were calculated to determine the discriminating power of mass peaks (i.e. features), of over $10 \%$ abundance, for the difference between captive and wild classes. Higher Fisher's ratios for a class relative to other classes indicate that the feature has a higher discriminating value for that class. Fisher's ratios are calculated as follows:

$$
\text { Fisher'sRatio }=\frac{\left(m_{1}-m_{2}\right)^{2}}{v_{1}+v_{2}}
$$

where $\mathrm{m}_{1}$ and $\mathrm{m}_{2}$ are the means for a feature in class 1 and class 2 , and $\mathrm{v}_{1}$ and $\mathrm{v}_{2}$ are the variances for class 1 and class 2 respectively. $m_{1}$ and $v_{1}$ represent the in-class mean and variance for the feature, and $\mathrm{m}_{2}$ and $\mathrm{v}_{2}$ represent the between-class mean and variance for the feature (Mass Mountaineer 2018).

Potential compound compositions were calculated for selected mass peaks with higher discriminating value (i.e. greater differences in Fisher's ratios) using the 'Composition' function of Mass Mountaineer. We chose mass peaks for which the Fisher's ratio for the captive class was approximately double-or-greater than the wild class (Table 5 in Appendix 3). Potential compound formulae generated by Mass Mountaineer were searched for in the online databases Chemspider (http://www.chemspider.com) and PubChem (https:// pubchem.ncbi.nlm.nih.gov/) and, where possible, tentative compound names were assigned.

We also searched spectra for matches to masses of commonly used veterinary tranquilizers and sedatives (Table 2) provided to us by a member of the lion bone trade industry.

\section{Results}

When wild samples from each individual lion, taken in duplicate, were considered as discrete classes duplicates largely overlaid each other in the KDA; indicating that the method produced replicable spectra $(99.32 \%$ variance covered on 3 Principal Components and $66.67 \%$ classification accuracy using leave-one-out cross-validation LOOCV) (Fig. 1). Replicates showed close matching of spectra (Fig. 2) and major features in those spectra were replicated.

Kernel Discriminant Analysis (KDA) showed clear separation between the spectra of captive-bred and wild lion bone samples (Fig. 3) with $97.50 \%$ classification accuracy using LOOCV. Three principal components accounted for $100 \%$ of the variance. A randomly selected captive-bred spectrum was excluded from the training set and was used as an unknown; it was successfully classified with KDA (Fig. 3).

Identification of the composition of mass peaks is not required for classification. However, we tentatively attempted to identify potential compounds that may be responsible for the key diagnostic mass peaks for the difference between captive-bred and wild lion bone spectra. At a level of $10 \%$ relative abundance peaks were selected based upon their Fisher's ratios (Table 5 in Appendix 3) and were tentatively assigned compound names (Table 1). 


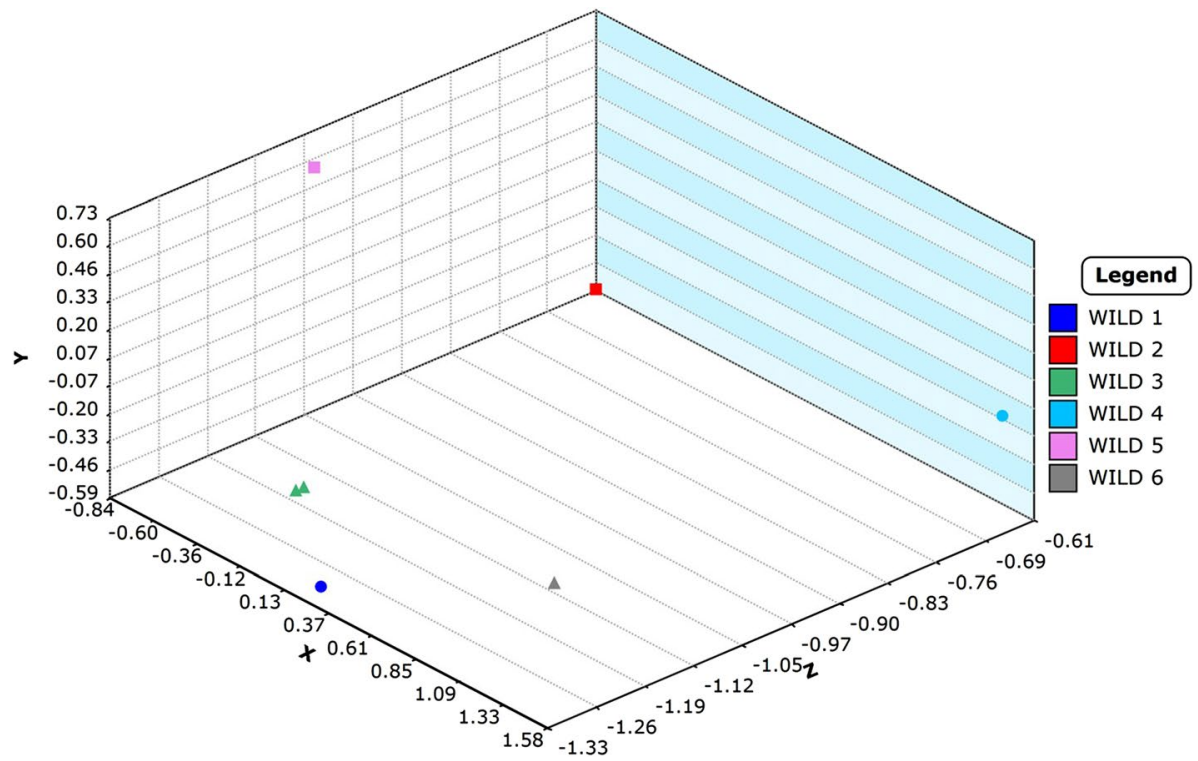

Fig. 1 Kernel Discriminant Analysis for wild lion samples; 6 individuals in duplicate (duplicate samples for WILD 1,2,4,5 \& 6 are effectively superimposed). 99.32\% variance covered on 3 Principal Components; $66.67 \%$ classification accuracy using LOOCV

We found no matches within the captive-bred spectra mass peaks for the masses of commonly used veterinary tranquilizers and sedatives (Table 2).

\section{Discussion}

The visual similarity of captive-bred lion bone to wild lion bone creates complications for the regulation and investigation of potentially illegal lion bone trade. To date, there has been no analytical method developed for accurately determining captive-bred lion bone from wild lion bone. We therefore conducted a preliminary investigation to determine whether Direct Analysis in Real Time (DART) mass spectrometry has potential to be used as a tool to distinguish between lion bone from captive-bred and wild sources. We found that DART analysis was able to reveal clear separation between a batch of captive-bred and a batch of wild lion bone mass spectra. This finding has relevance for discussions about the lion bone trade as the indistinguishability of captive from wild sources has been suggested to present a significant barrier to regulating lion bone trade and generating accurate intelligence concerning captive-bred or wild origins of lion products in the global market. We suggest that, with suitable techniques and resources, captive-bred and wild lion bones could be chemically distinguishable.

A well-acknowledged (but not sole) condition for farmed sources of wildlife to be considered non-detrimental is that its system of trade should not be vulnerable to the laundering of wild products (Dutton et al. 2013). In order to prevent laundering attempts, physical inspections, including verified 'chain of custody' for skeletons from farm to airport, have been undertaken for lion skeletons exported from South Africa as part of the 2017 and 

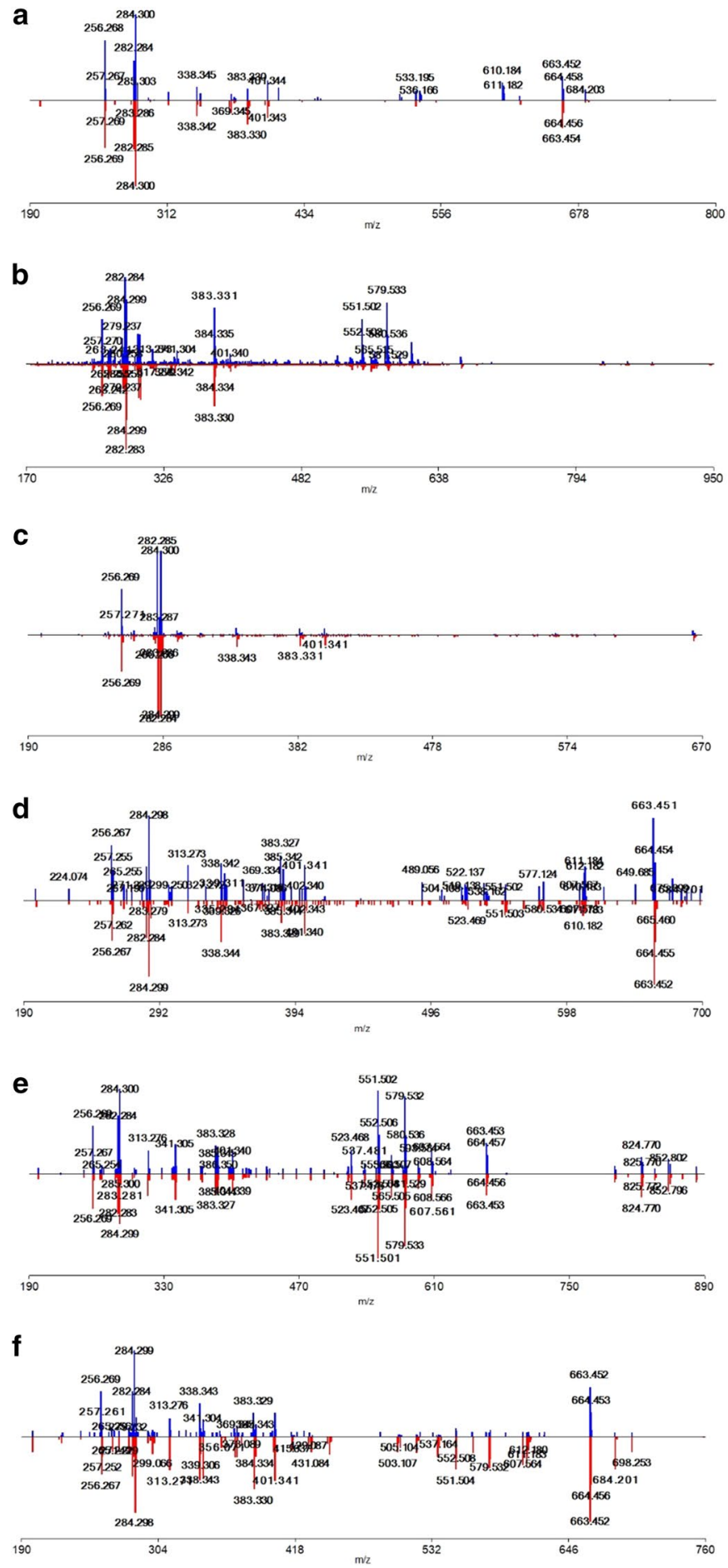

Fig. 2 Wild lion bone spectra duplicate matching (spectra $=$ blue, top; duplicate $=$ red, below). a Wild 1 ; $\mathbf{b}$ Wild 2; c Wild 3; d Wild 4; e Wild 5; f Wild 6 


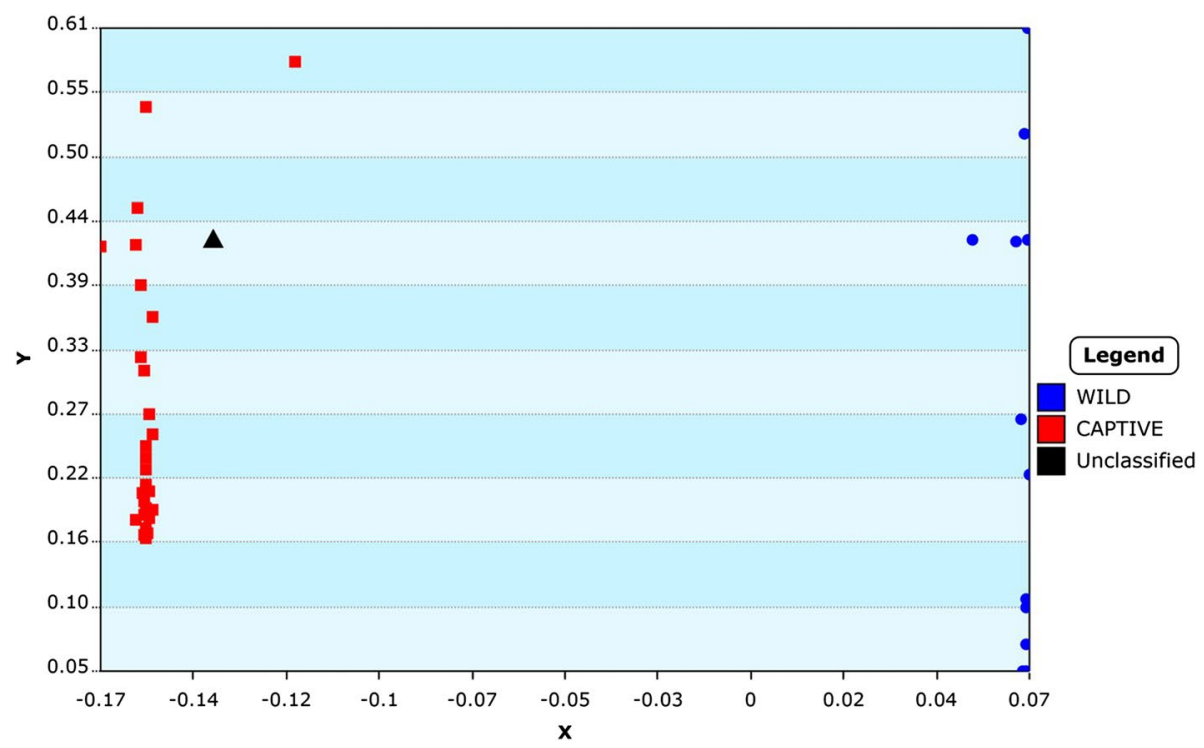

Fig. 3 Kernel Discriminant Analysis for separation between captive-bred and wild lion bone. Captive $\mathrm{n}=28$; Wild $\mathrm{n}=12$ (6 samples in duplicate). $100 \%$ variance covered on 3 Principal Components; $97.50 \%$ classification accuracy using LOOCV. 'Unknown' captive-bred sample (black) correctly grouped with other captive-bred samples

2018 export quotas (Williams et al. 2021). Although such measures largely prohibit any substitutions of skeletons after the first instance of inspection they do not provide surety of the captive-bred origin of skeletons (Williams et al. 2021). Our preliminary results, and others (e.g. Hutchinson and Roberts 2020), indicate that chemical methods, such as DART mass spectrometry, could provide such a measure. In addition, the relative contributions of wild and captive-bred lion parts in seizures and global end-markets are unknown and concerns have been raised that a conservation-significant contribution to overall trade may be made from wild animals (EIA 2017; Everatt et al. 2019). DART analysis shows potential to be able to provide information about the captive-bred origins of such lion products in illegal trade markets and seizures.

As a proof of concept this study used commercially captive-bred lion bone from South Africa and museum samples of wild-collected lion bone from Anglo-Egyptian Sudan (historical) in the early twentieth century. We were certain of the wild and captive origins of all samples in the study. Although DART analysis revealed clear separation between wild and captive-bred samples we cannot be certain that this separation is solely due to the wild or captive origin of the lions as additional variables could influence the result. Amongst these is the geographical area from which the samples originated. Indeed, bone, and other tissues, have been used to geo-locate biological samples through geographically variable chemical composition (although differences used in this way are often $\mathrm{O}$ and $\mathrm{H}$ isotope ratios e.g. Juarez 2008; Sugiyama et al. 2018). We searched spectra for, and removed, peaks generated by common contaminant compounds, it is thus unlikely that treatments such as cleaning solutions or plastic packaging lead to the observed differences. An additional, not-inconsiderable factor is the age of the bone sample and subsequent state of decomposition which may have influenced the observable difference between the two sample types. Although we treated common products of recent decomposition as contaminants and 


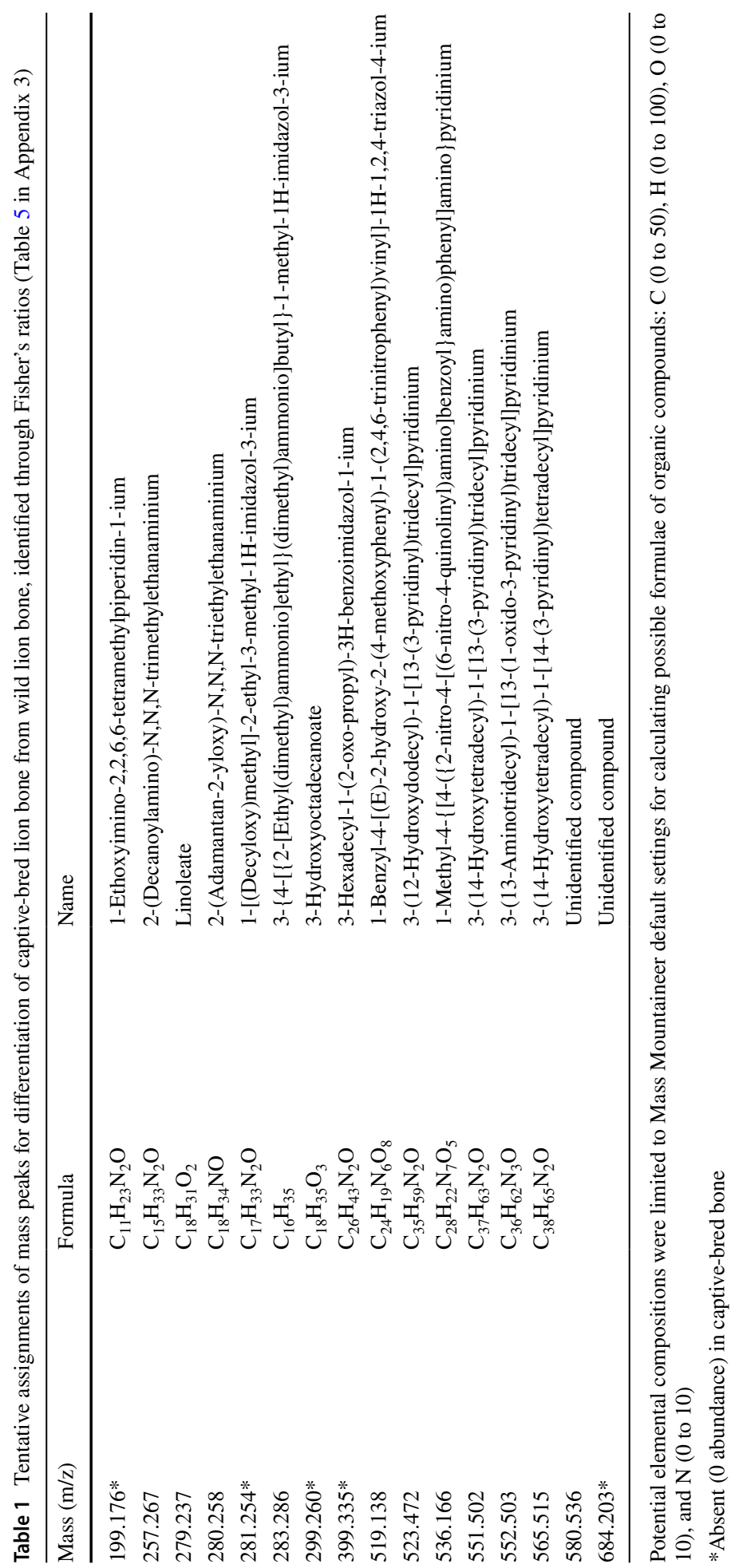


Table 2 Commonly used veterinary tranquilizers and sedatives in commercial lionhusbandry

\begin{tabular}{lll}
\hline Name & Formula & Mass $(\mathrm{m} / \mathrm{z})$ \\
\hline Ketamine & $\mathrm{C}_{13} \mathrm{H}_{16} \mathrm{ClNO}$ & 237.725 \\
Tiletamine & $\mathrm{C}_{12} \mathrm{H}_{17} \mathrm{NOS}$ & 223.335 \\
Zolazepam & $\mathrm{C}_{15} \mathrm{H}_{15} \mathrm{FN}_{4} \mathrm{O}$ & 286.304 \\
Xylazine & $\mathrm{C}_{12} \mathrm{H}_{16} \mathrm{~N}_{2} \mathrm{~S}$ & 220.334 \\
Medetomidine & $\mathrm{C}_{13} \mathrm{H}_{16} \mathrm{~N}_{2}$ & 200.279 \\
Midazolam & $\mathrm{C}_{18} \mathrm{H}_{13} \mathrm{ClFN}_{3}$ & 325.767 \\
\hline
\end{tabular}

removed them from analysis we cannot be certain of the influence of longer-term decomposition on captive-bred-wild sample differences.

The peaks identified from their Fisher's ratios as diagnostic for the separation between captive-bred and wild lion bone were large, complex compounds (Table 1). Of those tentatively assigned compounds several, containing imidazolium, pyridinium, and triazolium (Table 1), were of interest due to the use of imidazole, pyridine, and triazole derivatives in pharmaceutical drugs (including antibiotics and tranquilizers), and pesticides (e.g. Borgers 1980; Ross et al. 1980; Shimizu et al. 2000; Kharb et al. 2011). However, such derivatives are also naturally occurring biological molecules (Shimizu et al. 2000). In addition, a number of diagnostic compounds were found to occur in wild but not captive bones (Table 1). Therefore, we do not think it likely that man-made chemical additives are the main reason for the differing chemical compositions of captive-bred and wild lion bones. Nevertheless, we expected the different diets of captive-bred and wild lions to have an influence on body tissue chemical composition, and dietary studies across a range of organisms demonstrate the use of body tissue chemical composition to reflect dietary differences (e.g. Ambrose 1991; Cerling and Harris 1999; Katzenberg 2008). Our preliminary results suggest that amongst selected compounds with highly different Fisher's ratios there are absences in captive-bred lion bone that were found in wild lion bone. We cannot explain these differences. However, it is possible that the more restricted diet of captive-bred lions had an effect. Future work could beneficially focus on detailed examination of dietary specifics in the differentiation of wild and captive-bred origin lion bone.

The development and use of chemical profiling analyses in the monitoring of CITESassociated wildlife trade generally lags behind DNA-based techniques (Ogden and Mailley 2016). Nevertheless, we suggest that with further development DART mass spectrometry is likely to prove a useful tool in the regulation and investigation of lion bone trade. Although there is a long way to go before the use of DART analysis as a forensic method for lion bone trade, this study demonstrated that DART analysis can differentiate between a batch of captive-bred South African lion bones and bones of separate, wild origin. The development of robust forensic methods is difficult and often lengthy (Ogden and Mailley 2016) but for now DART analysis appears to be able to provide useful intelligence and research information for the lion bone trade. Future implementation of DART analysis into export regulation protocol as a screening method could be used to identify skeletons with chemical compositions that may be worthy of further investigation and verification of captive-bred origin. We searched captive-bred spectra for mass peaks of commonly used tranquilizers and veterinary sedatives (Table 2), we found no matches. This is unsurprising as we did not consider the metabolic products of these veterinary chemicals in detail, which can be complex and poorly understood (Tranquilli et al. 2013). Mass spectrometry is a key technique in the identification of drug metabolites (Zhu et al. 2011) and DART has been 
successfully used in the identification of trace amounts of drug metabolites (Sisco et al. 2016). However, our primary research objective was not to identify specific chemical markers, rather to broadly differentiate between captive-bred and wild lion bone spectra. The identification of specific chemical markers in captive-bred lion bone, of which we believe veterinary drugs are likely candidates, would greatly aid in the detection of captive-bred lion bone. In addition, the mandatory introduction of suitable markers by lion breeders and keepers should also be considered. We thus suggest that refining knowledge of chemical markers in captive-bred lion bone is an important area upon which future research effort could focus.

DART analysis provides significant operational benefit over other chemical techniques (such as stable isotope analysis) due to the speed with which mass spectra can be generated (in this study a DART Quickstrip of 12 samples was analysed in approximately two minutes). Time was added to our method by the powdering of bone. Powdering was deemed necessary to present a more homogenous sample than introduction of a whole bone piece; which is likely to be prone to high levels of variation in thickness and surface composition. Preparation times of powdered bone samples were approximately $10 \mathrm{~min}$ per sample, including waiting time for the evaporation of ethanol from the DART Quickstrip mesh. Even with the added sample preparation time, DART is a suitable method for rapid result generation from lion bone. In addition, further attention is being given to the development of detection and analysis equipment that can be used for 'in-the-field' (i.e. decentralised) wildlife trade investigations (Morrison et al. 2018; Masters et al. 2019). The development of robust, portable DART technology (e.g. Wells et al. 2008) further increases the potential utility of such an approach to support lion bone trade investigations, especially in key locations of concern for the lion bone trade which may lie in regions of weaker laboratory capacity for the investigation of wildlife crime (Williams et al. 2017b; Ogden and Mailley 2016).

\section{Conclusion}

In response to a lack of analytical techniques to differentiate between captive-bred and wild sources of lion bone in trade we tested the potential of Direct Analysis in Real Time (DART) mass spectrometry to differentiate between captive-bred and wild lion bone samples. We found that DART analysis was able to differentiate between two batches of visually indistinguishable lion bone powders; one from contemporary South African captivebred lion bones and the other from historical Sudanese wild lion bones. We suggest that DART analysis shows good potential as an emerging tool for the investigation of the origin of lion bones in trade. At present the future of the legal trade in lion skeletons from South Africa is uncertain. However, regardless of the future legality of captive-bred lion bone trade, we anticipate a continued requirement for effective methods of captive-bred and wild differentiation; either in the regulation of legal trade or investigation of illegal trade. 


\section{Appendix 1}

See Table 3.

Table 3 Accession numbers of 29 captive-bred lion bone samples at the National

Zoological Gardens of South

Africa used for DART analysis

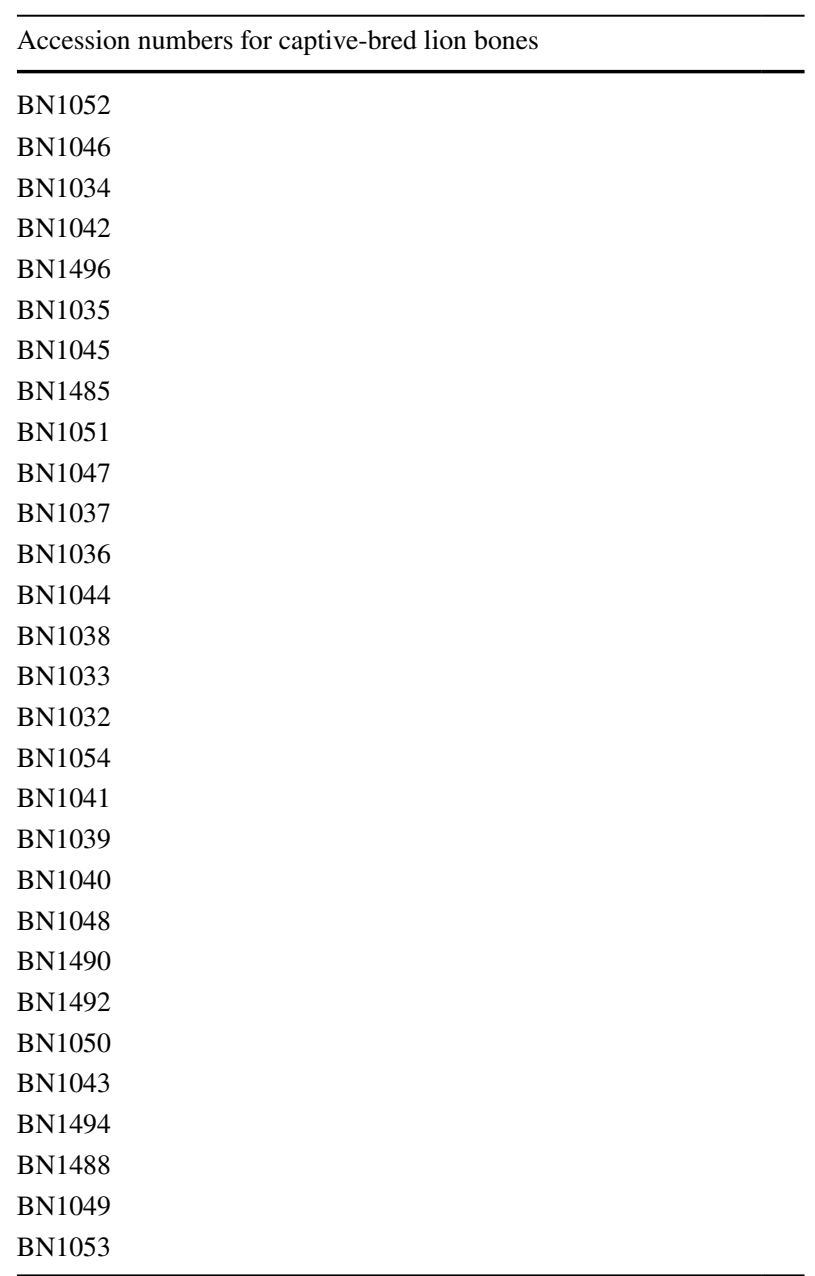




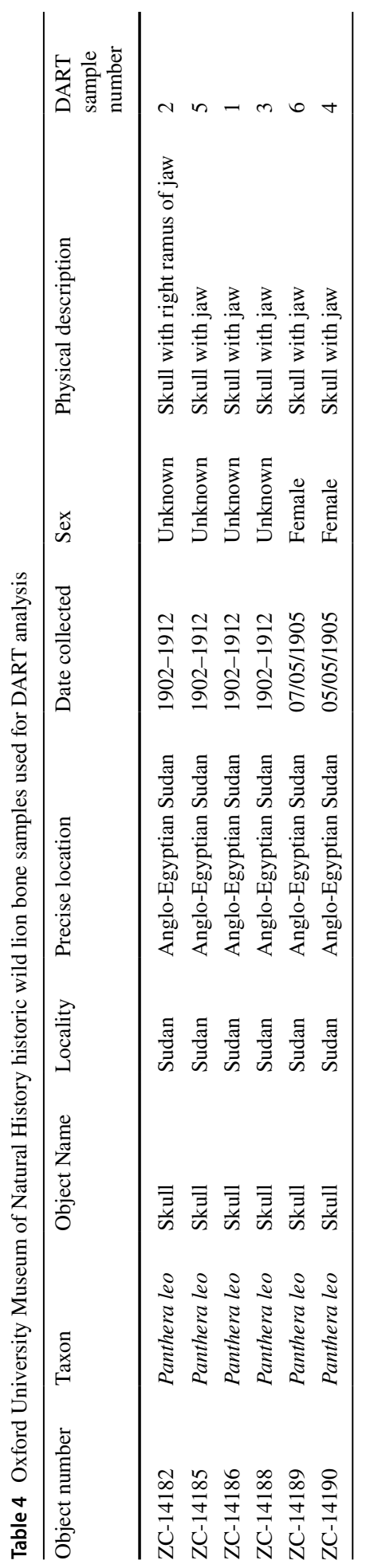

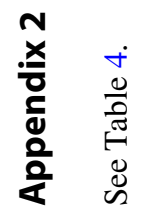




\section{Appendix 3}

See Table 5.

Table 5 Fisher's ratios for difference between captive-bred and wild lion bone samples calculated at $10 \%$ abundance threshold

\begin{tabular}{|c|c|c|c|c|}
\hline Class index & Class name & Fisher's ratio & Abundance & Variance \\
\hline 199.1764069 & - & - & & \\
\hline 0 & WILD & 494.667523 & 15,523 & $5,740,816$ \\
\hline 1 & CAPTIVE & 935.818658 & 0 & 0 \\
\hline 224.0738068 & - & - & & \\
\hline 0 & WILD & 0 & 13,513 & 0 \\
\hline 1 & CAPTIVE & 0 & 0 & 0 \\
\hline 229.1502991 & - & - & & \\
\hline 0 & WILD & 100.364687 & 0 & 0 \\
\hline 1 & CAPTIVE & 83.481721 & $13,741.1765$ & $9,511,833.91$ \\
\hline 245.2312012 & - & - & & \\
\hline 0 & WILD & 0 & 0 & 0 \\
\hline 1 & CAPTIVE & 0 & 12,100 & 0 \\
\hline 247.245697 & - & - & & \\
\hline 0 & WILD & 248.70471 & 0 & 0 \\
\hline 1 & CAPTIVE & 172.528972 & $12,771.4286$ & $7,239,183.673$ \\
\hline 256.2683105 & - & - & & \\
\hline 0 & WILD & 7.428018 & 51,539 & $86,436,053.5$ \\
\hline 1 & CAPTIVE & 6.036091 & $39,427.3793$ & $200,285,829.9$ \\
\hline 257.26651 & - & - & & \\
\hline 0 & WILD & 7.018523 & 16,253 & $62,322,439.33$ \\
\hline 1 & CAPTIVE & 19.976187 & $11,085.7143$ & $629,795.9184$ \\
\hline 263.2414856 & - & - & & \\
\hline 0 & WILD & 39.045456 & 16,450 & 722,500 \\
\hline 1 & CAPTIVE & 15.098694 & $14,071.4286$ & $6,467,755.102$ \\
\hline 265.2565002 & - & - & & \\
\hline 0 & WILD & 4.080715 & $14,564.5$ & $14,329,668.92$ \\
\hline 1 & CAPTIVE & 2.70345 & $18,295.4545$ & $57,774,979.34$ \\
\hline 267.1901855 & - & - & & \\
\hline 0 & WILD & 0 & 13,127 & 0 \\
\hline 1 & CAPTIVE & 0 & 0 & 0 \\
\hline 271.2286072 & - & - & & \\
\hline 0 & WILD & 1024.084797 & $17,839.5$ & 6320.25 \\
\hline 1 & CAPTIVE & 1024.918582 & 0 & 0 \\
\hline 277.2210083 & - & - & & \\
\hline 0 & WILD & 0 & 0 & 0 \\
\hline 1 & CAPTIVE & 0 & 16,200 & 0 \\
\hline 279.1705017 & - & - & & \\
\hline 0 & WILD & 0 & 15,444 & 0 \\
\hline 1 & CAPTIVE & 0 & 0 & 0 \\
\hline
\end{tabular}


Table 5 (continued)

\begin{tabular}{|c|c|c|c|c|}
\hline Class index & Class name & Fisher's ratio & Abundance & Variance \\
\hline 279.2367859 & - & - & & \\
\hline 0 & WILD & 6.385084 & $21,779.5$ & $58,993,132.75$ \\
\hline 1 & CAPTIVE & 13.73945 & $17,316.6667$ & $17,251,388.89$ \\
\hline 280.2583923 & - & - & & \\
\hline 0 & WILD & 1.451757 & $11,133.3333$ & $815,555.5556$ \\
\hline 1 & CAPTIVE & 11.156153 & 10,900 & 0 \\
\hline 281.2542114 & - & - & & \\
\hline 0 & WILD & 309.377798 & 24,700 & $31,360,000$ \\
\hline 1 & CAPTIVE & 850.192718 & 0 & 0 \\
\hline 282.2840881 & - & - & & \\
\hline 0 & WILD & 2.879713 & $66,704.0833$ & $579,072,355.9$ \\
\hline 1 & CAPTIVE & 2.886329 & $81,250.8621$ & $574,861,538$ \\
\hline 283.2862854 & - & - & & \\
\hline 0 & WILD & 0.027961 & $19,932.4545$ & $53,685,652.07$ \\
\hline 1 & CAPTIVE & 0.04513 & $20,270.3704$ & $14,844,307.27$ \\
\hline 284.2997131 & - & - & & \\
\hline 0 & WILD & 7.711279 & $89,426.3333$ & $211,309,397.4$ \\
\hline 1 & CAPTIVE & 6.048276 & $68,737.1379$ & $592,868,918.1$ \\
\hline 285.0177917 & - & - & & \\
\hline 0 & WILD & 0 & 12,741 & 0 \\
\hline 1 & CAPTIVE & 0 & 0 & 0 \\
\hline 285.302887 & - & - & & \\
\hline 0 & WILD & 3.423868 & 19,157 & $17,317,462.83$ \\
\hline 1 & CAPTIVE & 4.096744 & $16,754.1667$ & $10,393,315.97$ \\
\hline 297.2461853 & - & - & & \\
\hline 0 & WILD & 477.188082 & 36,750 & $5,062,500$ \\
\hline 1 & CAPTIVE & 658.063688 & 18,000 & 0 \\
\hline 299.0657959 & - & - & & \\
\hline 0 & WILD & 0 & 19,075 & 0 \\
\hline 1 & CAPTIVE & 0 & 0 & 0 \\
\hline 299.260498 & - & - & & \\
\hline 0 & WILD & 128.726333 & 28,054 & $95,770,394$ \\
\hline 1 & CAPTIVE & 344.712732 & 0 & 0 \\
\hline 301.0643921 & - & - & & \\
\hline 0 & WILD & 0 & 16,988 & 0 \\
\hline 1 & CAPTIVE & 0 & 0 & 0 \\
\hline 309.2788086 & - & - & & \\
\hline 0 & WILD & 0 & 0 & 0 \\
\hline 1 & CAPTIVE & 0 & 11,300 & 0 \\
\hline 311.2598877 & - & - & & \\
\hline 0 & WILD & 112.169325 & 0 & 0 \\
\hline 1 & CAPTIVE & 96.734658 & 13,200 & $6,196,250$ \\
\hline 313.2727051 & - & - & & \\
\hline 0 & WILD & 3.809944 & 26,598 & $92,385,346.29$ \\
\hline 1 & CAPTIVE & 3.25468 & 33,848 & $151,227,451.7$ \\
\hline
\end{tabular}


Table 5 (continued)

\begin{tabular}{|c|c|c|c|c|}
\hline Class index & Class name & Fisher's ratio & Abundance & Variance \\
\hline 314.2771912 & - & - & & \\
\hline 0 & WILD & 245.482551 & 0 & 0 \\
\hline 1 & CAPTIVE & 221.619756 & 12,350 & $1,672,500$ \\
\hline 317.2698975 & - & - & & \\
\hline 0 & WILD & 0 & 10,000 & 0 \\
\hline 1 & CAPTIVE & 0 & 0 & 0 \\
\hline 321.3160095 & - & - & & \\
\hline 0 & WILD & 963.21163 & 0 & 0 \\
\hline 1 & CAPTIVE & 595.352823 & 11,450 & $2,102,500$ \\
\hline 323.262085 & - & - & & \\
\hline 0 & WILD & 0 & 0 & 0 \\
\hline 1 & CAPTIVE & 0 & 16,600 & 0 \\
\hline 325.2687988 & - & - & & \\
\hline 0 & WILD & 1003.913804 & 0 & 0 \\
\hline 1 & CAPTIVE & 829.090214 & 13,800 & $1,000,000$ \\
\hline 326.3428955 & - & - & & \\
\hline 0 & WILD & 891.125072 & 0 & 0 \\
\hline 1 & CAPTIVE & 381.026337 & 12,900 & $6,250,000$ \\
\hline 327.2539978 & - & - & & \\
\hline 0 & WILD & 0 & 0 & 0 \\
\hline 1 & CAPTIVE & 0 & 10,100 & 0 \\
\hline 327.2720947 & - & - & & \\
\hline 0 & WILD & 0 & 16,988 & 0 \\
\hline 1 & CAPTIVE & 0 & 0 & 0 \\
\hline 335.2907104 & - & - & & \\
\hline 0 & WILD & 0 & 11,010 & 0 \\
\hline 1 & CAPTIVE & 0 & 0 & 0 \\
\hline 336.2547913 & - & - & & \\
\hline 0 & WILD & 0 & 0 & 0 \\
\hline 1 & CAPTIVE & 0 & 11,600 & 0 \\
\hline 337.2730103 & - & - & & \\
\hline 0 & WILD & 114.983589 & 0 & 0 \\
\hline 1 & CAPTIVE & 94.494314 & $13,626.6667$ & $8,753,955.556$ \\
\hline 338.3445129 & - & - & & \\
\hline 0 & WILD & 1.53228 & $30,063.25$ & $257,171,939.9$ \\
\hline 1 & CAPTIVE & 1.199443 & $38,099.72$ & $549,576,200.2$ \\
\hline 339.2909851 & - & - & & \\
\hline 0 & WILD & 52.072662 & 0 & 0 \\
\hline 1 & CAPTIVE & 40.078295 & $58,711.36$ & $495,270,655.6$ \\
\hline 339.3109131 & - & - & & \\
\hline 0 & WILD & 102.162332 & 17,850 & $8,753,850$ \\
\hline 1 & CAPTIVE & 22.963303 & $33,199.6667$ & $207,607,066.9$ \\
\hline 339.3388977 & - & - & & \\
\hline 0 & WILD & 640.810913 & 13,725 & 0 \\
\hline 1 & CAPTIVE & 391.254553 & 22,600 & $1,960,000$ \\
\hline
\end{tabular}


Table 5 (continued)

\begin{tabular}{|c|c|c|c|c|}
\hline Class index & Class name & Fisher's ratio & Abundance & Variance \\
\hline 340.2948914 & - & - & & \\
\hline 0 & WILD & 92.250171 & 0 & 0 \\
\hline 1 & CAPTIVE & 79.770433 & $17,473.6842$ & $12,945,096.95$ \\
\hline 341.0227051 & - & - & & \\
\hline 0 & WILD & 0 & 12,741 & 0 \\
\hline 1 & CAPTIVE & 0 & 0 & 0 \\
\hline 341.3035889 & - & - & & \\
\hline 0 & WILD & 17.153188 & $28,070.7143$ & $135,611,587.6$ \\
\hline 1 & CAPTIVE & 35.443278 & $15,241.1765$ & $11,817,716.26$ \\
\hline 342.310791 & - & - & & \\
\hline 0 & WILD & 0 & 18,147 & 0 \\
\hline 1 & CAPTIVE & 0 & 0 & 0 \\
\hline 352.3568115 & - & - & & \\
\hline 0 & WILD & 1024.968886 & 0 & 0 \\
\hline 1 & CAPTIVE & 1024.650075 & 18,150 & 2500 \\
\hline 353.2622986 & - & - & & \\
\hline 0 & WILD & 128.642658 & 0 & 0 \\
\hline 1 & CAPTIVE & 90.471937 & $16,666.6667$ & $22,775,555.56$ \\
\hline 355.2528992 & - & - & & \\
\hline 0 & WILD & 255.6921 & 0 & 0 \\
\hline 1 & CAPTIVE & 137.487671 & 15,100 & $19,166,666.67$ \\
\hline 355.2802124 & - & - & & \\
\hline 0 & WILD & 127.788735 & 24,324 & 0 \\
\hline 1 & CAPTIVE & 77.715061 & 15,180 & $10,539,600$ \\
\hline 356.071106 & - & - & & \\
\hline 0 & WILD & 0 & 13,295 & 0 \\
\hline 1 & CAPTIVE & 0 & 0 & 0 \\
\hline 357.3005981 & - & - & & \\
\hline 0 & WILD & 427.058485 & 0 & 0 \\
\hline 1 & CAPTIVE & 230.292815 & 15,775 & $12,446,875$ \\
\hline 360.3265076 & - & - & & \\
\hline 0 & WILD & 0 & 0 & 0 \\
\hline 1 & CAPTIVE & 0 & 13,000 & 0 \\
\hline 367.3268127 & - & - & & \\
\hline 0 & WILD & 1.438044 & $17,417.5$ & $47,052,740.25$ \\
\hline 1 & CAPTIVE & 2.667532 & 15,475 & $16,818,125$ \\
\hline 369.2341919 & - & - & & \\
\hline 0 & WILD & 177.088731 & 0 & 0 \\
\hline 1 & CAPTIVE & 117.519312 & $14,755.5556$ & $15,580,246.91$ \\
\hline 369.3454895 & - & - & & \\
\hline 0 & WILD & 1.822486 & 17,931 & $23,174,926.5$ \\
\hline 1 & CAPTIVE & 1.07154 & $23,771.92$ & $351,148,147.6$ \\
\hline 370.3526917 & - & - & & \\
\hline 0 & WILD & 742.999133 & 0 & 0 \\
\hline 1 & CAPTIVE & 194.50195 & 22,400 & $47,610,000$ \\
\hline
\end{tabular}


Table 5 (continued)

\begin{tabular}{|c|c|c|c|c|}
\hline Class index & Class name & Fisher's ratio & Abundance & Variance \\
\hline 371.3164063 & - & - & & \\
\hline 0 & WILD & 0 & 14,286 & 0 \\
\hline 1 & CAPTIVE & 0 & 0 & 0 \\
\hline 373.0892944 & - & - & & \\
\hline 0 & WILD & 0 & 10,116 & 0 \\
\hline 1 & CAPTIVE & 0 & 0 & 0 \\
\hline 374.0856018 & - & - & & \\
\hline 0 & WILD & 0 & 13,513 & 0 \\
\hline 1 & CAPTIVE & 0 & 0 & 0 \\
\hline 383.2466125 & - & - & & \\
\hline 0 & WILD & 176.022388 & 0 & 0 \\
\hline 1 & CAPTIVE & 115.990865 & $20,422.2222$ & $30,657,283.95$ \\
\hline 383.3089905 & - & - & & \\
\hline 0 & WILD & 222.135765 & 0 & 0 \\
\hline 1 & CAPTIVE & 130.115963 & $18,857.1429$ & $28,302,448.98$ \\
\hline 383.3299866 & - & - & & \\
\hline 0 & WILD & 11.292015 & 35,800 & $314,185,733.5$ \\
\hline 1 & CAPTIVE & 23.906249 & $19,988.8889$ & $22,145,432.1$ \\
\hline 384.3351135 & - & - & & \\
\hline 0 & WILD & 366.718276 & 17,842 & $5,165,252$ \\
\hline 1 & CAPTIVE & 481.264513 & 0 & 0 \\
\hline 385.3417053 & - & - & & \\
\hline 0 & WILD & 18.964344 & $22,111.8333$ & $60,244,434.47$ \\
\hline 1 & CAPTIVE & 42.077025 & $13,491.6667$ & $6,437,430.556$ \\
\hline 386.3457031 & - & - & & \\
\hline 0 & WILD & 13.404296 & $11,861.5$ & $2,727,452.25$ \\
\hline 1 & CAPTIVE & 5.766002 & 13,300 & $7,840,000$ \\
\hline 391.2893982 & - & - & & \\
\hline 0 & WILD & 0 & 15,058 & 0 \\
\hline 1 & CAPTIVE & 0 & 0 & 0 \\
\hline 397.3198853 & - & - & & \\
\hline 0 & WILD & 0 & 13,899 & 0 \\
\hline 1 & CAPTIVE & 0 & 0 & 0 \\
\hline 399.3351135 & - & - & & \\
\hline 0 & WILD & 446.125435 & 15,812 & $7,209,225$ \\
\hline 1 & CAPTIVE & 919.003369 & 0 & 0 \\
\hline 401.3435974 & - & - & & \\
\hline 0 & WILD & 4.393809 & $27,484.2$ & $151,569,123$ \\
\hline 1 & CAPTIVE & 3.069039 & $40,935.72$ & $595,975,012.4$ \\
\hline 402.3396912 & - & - & & \\
\hline 0 & WILD & 21.099731 & $14,032.5$ & $6,602,330.25$ \\
\hline 1 & CAPTIVE & 10.675194 & $19,190.9091$ & $37,389,917.36$ \\
\hline 411.4000854 & - & - & & \\
\hline 0 & WILD & 0 & 14,539 & 0 \\
\hline 1 & CAPTIVE & 0 & 10,600 & 0 \\
\hline
\end{tabular}


Table 5 (continued)

\begin{tabular}{|c|c|c|c|c|}
\hline Class index & Class name & Fisher's ratio & Abundance & Variance \\
\hline 415.0372925 & - & - & & \\
\hline 0 & WILD & 0 & 15,896 & 0 \\
\hline 1 & CAPTIVE & 0 & 0 & 0 \\
\hline 425.3422852 & - & - & & \\
\hline 0 & WILD & 678.232399 & 0 & 0 \\
\hline 1 & CAPTIVE & 645.315288 & $11,033.3333$ & $228,888.8889$ \\
\hline 429.0870056 & - & - & & \\
\hline 0 & WILD & 0 & 11,272 & 0 \\
\hline 1 & CAPTIVE & 0 & 0 & 0 \\
\hline 429.3714905 & - & - & & \\
\hline 0 & WILD & 0 & 0 & 0 \\
\hline 1 & CAPTIVE & 0 & 14,300 & 0 \\
\hline 431.0842896 & - & - & & \\
\hline 0 & WILD & 0 & 18,208 & 0 \\
\hline 1 & CAPTIVE & 0 & 0 & 0 \\
\hline 432.0798035 & - & - & & \\
\hline 0 & WILD & 0 & 10,116 & 0 \\
\hline 1 & CAPTIVE & 0 & 0 & 0 \\
\hline 437.3510132 & - & - & & \\
\hline 0 & WILD & 980.865554 & 0 & 0 \\
\hline 1 & CAPTIVE & 680.521262 & 13,200 & $1,960,000$ \\
\hline 439.3474121 & - & - & & \\
\hline 0 & WILD & 85.021148 & 0 & 0 \\
\hline 1 & CAPTIVE & 65.975509 & $16,666.6667$ & $23,578,888.89$ \\
\hline 445.3673096 & - & - & & \\
\hline 0 & WILD & 0 & 0 & 0 \\
\hline 1 & CAPTIVE & 0 & 13,100 & 0 \\
\hline 446.1213074 & - & - & & \\
\hline 0 & WILD & 0 & 21,098 & 0 \\
\hline 1 & CAPTIVE & 0 & 0 & 0 \\
\hline 451.3485107 & - & - & & \\
\hline 0 & WILD & 483.009379 & 0 & 0 \\
\hline 1 & CAPTIVE & 373.007232 & 12,500 & $2,385,000$ \\
\hline 453.353302 & - & - & & \\
\hline 0 & WILD & 61.042662 & 0 & 0 \\
\hline 1 & CAPTIVE & 44.694887 & $22,814.2857$ & $77,968,843.54$ \\
\hline 454.3604126 & - & - & & \\
\hline 0 & WILD & 400.435913 & 0 & 0 \\
\hline 1 & CAPTIVE & 365.480993 & 11,060 & 730,400 \\
\hline 455.3648987 & - & - & & \\
\hline 0 & WILD & 131.389376 & 0 & 0 \\
\hline 1 & CAPTIVE & 104.027179 & $14,938.4615$ & $11,168,520.71$ \\
\hline 465.3575134 & - & - & & \\
\hline 0 & WILD & 72.456875 & 0 & 0 \\
\hline 1 & CAPTIVE & 57.890394 & $19,247.619$ & $32,163,446.71$ \\
\hline
\end{tabular}


Table 5 (continued)

\begin{tabular}{|c|c|c|c|c|}
\hline Class index & Class name & Fisher's ratio & Abundance & Variance \\
\hline 466.3645935 & - & - & & \\
\hline 0 & WILD & 0 & 0 & 0 \\
\hline 1 & CAPTIVE & 0 & 10,500 & 0 \\
\hline 467.3705139 & - & - & & \\
\hline 0 & WILD & 46.842267 & 0 & 0 \\
\hline 1 & CAPTIVE & 35.485521 & $46,653.4231$ & $371,767,877.2$ \\
\hline 468.3747864 & - & - & & \\
\hline 0 & WILD & 80.416727 & 0 & 0 \\
\hline 1 & CAPTIVE & 65.870389 & 17,230 & $20,381,100$ \\
\hline 469.3612061 & - & - & & \\
\hline 0 & WILD & 1017.173183 & 0 & 0 \\
\hline 1 & CAPTIVE & 943.339707 & 11,400 & 250,000 \\
\hline 479.3622131 & - & - & & \\
\hline 0 & WILD & 88.197345 & 0 & 0 \\
\hline 1 & CAPTIVE & 66.618892 & $17,464.7059$ & $28,004,636.68$ \\
\hline 481.3711853 & - & - & & \\
\hline 0 & WILD & 83.505703 & 0 & 0 \\
\hline 1 & CAPTIVE & 64.046374 & 20,350 & $37,669,166.67$ \\
\hline 482.3829956 & - & - & & \\
\hline 0 & WILD & 0 & 0 & 0 \\
\hline 1 & CAPTIVE & 0 & 10,300 & 0 \\
\hline 483.3699036 & - & - & & \\
\hline 0 & WILD & 229.467346 & 0 & 0 \\
\hline 1 & CAPTIVE & 180.992698 & 12,150 & $4,307,500$ \\
\hline 489.0563965 & - & - & & \\
\hline 0 & WILD & 0 & 21,235 & 0 \\
\hline 1 & CAPTIVE & 0 & 0 & 0 \\
\hline 491.3699036 & - & - & & \\
\hline 0 & WILD & 498.31783 & 0 & 0 \\
\hline 1 & CAPTIVE & 436.423507 & 11,475 & 936,875 \\
\hline 493.3811951 & - & - & & \\
\hline 0 & WILD & 49.195914 & 0 & 0 \\
\hline 1 & CAPTIVE & 37.945101 & $32,538.3462$ & $159,525,506.6$ \\
\hline 494.3898926 & - & - & & \\
\hline 0 & WILD & 146.439447 & 0 & 0 \\
\hline 1 & CAPTIVE & 117.722382 & $14,783.3333$ & $9,101,388.889$ \\
\hline 495.3893127 & - & - & & \\
\hline 0 & WILD & 94.336279 & 0 & 0 \\
\hline 1 & CAPTIVE & 74.720647 & $18,382.3529$ & $23,508,512.11$ \\
\hline 495.4046021 & - & - & & \\
\hline 0 & WILD & 93.605749 & 0 & 0 \\
\hline 1 & CAPTIVE & 73.71548 & $18,176.4706$ & $23,808,858.13$ \\
\hline 503.1065979 & - & - & & \\
\hline 0 & WILD & 0 & 18,497 & 0 \\
\hline 1 & CAPTIVE & 0 & 0 & 0 \\
\hline
\end{tabular}


Table 5 (continued)

\begin{tabular}{|c|c|c|c|c|}
\hline Class index & Class name & Fisher's ratio & Abundance & Variance \\
\hline 504.1076965 & - & - & & \\
\hline 0 & WILD & 0 & 12,741 & 0 \\
\hline 1 & CAPTIVE & 0 & 0 & 0 \\
\hline 505.104187 & - & - & & \\
\hline 0 & WILD & 0 & 13,006 & 0 \\
\hline 1 & CAPTIVE & 0 & 0 & 0 \\
\hline 507.3703003 & - & - & & \\
\hline 0 & WILD & 324.911024 & 0 & 0 \\
\hline 1 & CAPTIVE & 278.28293 & $11,283.3333$ & $1,641,388.889$ \\
\hline 509.3848877 & - & - & & \\
\hline 0 & WILD & 197.168098 & 0 & 0 \\
\hline 1 & CAPTIVE & 150.959789 & $12,277.7778$ & $5,850,617.284$ \\
\hline 519.1381836 & - & - & & \\
\hline 0 & WILD & 319.783443 & 17,501 & $1,651,225$ \\
\hline 1 & CAPTIVE & 620.617193 & 10,900 & 0 \\
\hline 520.5014038 & - & - & & \\
\hline 0 & WILD & 0 & 0 & 0 \\
\hline 1 & CAPTIVE & 0 & 10,300 & 0 \\
\hline 521.4511719 & - & - & & \\
\hline 0 & WILD & 221.147073 & 0 & 0 \\
\hline 1 & CAPTIVE & 163.687847 & $13,662.5$ & $7,407,343.75$ \\
\hline 522.1367798 & - & - & & \\
\hline 0 & WILD & 0 & 18,533 & 0 \\
\hline 1 & CAPTIVE & 0 & 0 & 0 \\
\hline 523.4718018 & - & - & & \\
\hline 0 & WILD & 8.298666 & $21,185.75$ & $63,512,816.19$ \\
\hline 1 & CAPTIVE & 18.372601 & 15,625 & $12,435,625$ \\
\hline 533.1945801 & - & - & & \\
\hline 0 & WILD & 0 & 11,702 & 0 \\
\hline 1 & CAPTIVE & 0 & 0 & 0 \\
\hline 536.1657715 & - & - & & \\
\hline 0 & WILD & 4.920255 & $18,181.6667$ & $24,900,656.89$ \\
\hline 1 & CAPTIVE & 36.169174 & 15,800 & 0 \\
\hline 537.1638184 & - & - & & \\
\hline 0 & WILD & 0 & 10,694 & 0 \\
\hline 1 & CAPTIVE & 0 & 0 & 0 \\
\hline 537.4810181 & - & - & & \\
\hline 0 & WILD & 854.695896 & $13,983.5$ & $865,830.25$ \\
\hline 1 & CAPTIVE & 1007.161429 & 0 & 0 \\
\hline 538.1621094 & - & - & & \\
\hline 0 & WILD & 865.58892 & $11,137.5$ & $507,656.25$ \\
\hline 1 & CAPTIVE & 1008.490792 & 0 & 0 \\
\hline 547.468689 & - & - & & \\
\hline 0 & WILD & 96.287302 & 0 & 0 \\
\hline 1 & CAPTIVE & 77.463056 & $15,341.1765$ & $14,849,480.97$ \\
\hline
\end{tabular}


Table 5 (continued)

\begin{tabular}{|c|c|c|c|c|}
\hline Class index & Class name & Fisher's ratio & Abundance & Variance \\
\hline 548.4746094 & - & - & & \\
\hline 0 & WILD & 0 & 0 & 0 \\
\hline 1 & CAPTIVE & 0 & 10,300 & 0 \\
\hline 549.4857178 & - & - & & \\
\hline 0 & WILD & 52.351399 & 0 & 0 \\
\hline 1 & CAPTIVE & 39.342647 & $33,545.7083$ & $177,687,835.9$ \\
\hline 550.4893188 & - & - & & \\
\hline 0 & WILD & 98.960271 & 0 & 0 \\
\hline 1 & CAPTIVE & 81.36309 & $16,270.5882$ & $14,464,429.07$ \\
\hline 551.5015259 & - & - & & \\
\hline 0 & WILD & 4.677523 & $53,415.3333$ & $1,199,762,890$ \\
\hline 1 & CAPTIVE & 9.175364 & $34,249.7917$ & $237,381,687.7$ \\
\hline 552.5032959 & - & - & & \\
\hline 0 & WILD & 10.952528 & $28,142.8333$ & $139,108,302.1$ \\
\hline 1 & CAPTIVE & 20.483431 & 17,890 & $27,461,900$ \\
\hline 553.5032959 & - & - & & \\
\hline 0 & WILD & 851.949692 & 11,059 & 552,049 \\
\hline 1 & CAPTIVE & 1006.821486 & 0 & 0 \\
\hline 563.4750977 & - & - & & \\
\hline 0 & WILD & 246.292214 & 0 & 0 \\
\hline 1 & CAPTIVE & 223.987971 & $11,862.5$ & $1,422,343.75$ \\
\hline 563.4927979 & - & - & & \\
\hline 0 & WILD & 221.233865 & 0 & 0 \\
\hline 1 & CAPTIVE & 207.645712 & $11,377.7778$ & $957,283.9506$ \\
\hline 565.4874878 & - & - & & \\
\hline 0 & WILD & 370.48652 & 0 & 0 \\
\hline 1 & CAPTIVE & 265.556074 & 12,960 & $4,478,400$ \\
\hline 565.5145264 & - & - & & \\
\hline 0 & WILD & 71.318095 & $20,696.5$ & $17,905,214.25$ \\
\hline 1 & CAPTIVE & 230.943078 & 12,100 & 0 \\
\hline 566.5073242 & - & - & & \\
\hline 0 & WILD & 884.016391 & 10,633 & 400,689 \\
\hline 1 & CAPTIVE & 1010.672636 & 0 & 0 \\
\hline 573.4857788 & - & - & & \\
\hline 0 & WILD & 394.919334 & 0 & 0 \\
\hline 1 & CAPTIVE & 343.167404 & 11,260 & $1,210,400$ \\
\hline 575.5028076 & - & - & & \\
\hline 0 & WILD & 44.855013 & 0 & 0 \\
\hline 1 & CAPTIVE & 33.476104 & $36,665.1538$ & $254,684,070.6$ \\
\hline 576.5050049 & - & - & & \\
\hline 0 & WILD & 85.866945 & 0 & 0 \\
\hline 1 & CAPTIVE & 70.366712 & $17,805.2632$ & $20,332,077.56$ \\
\hline 577.1240234 & - & - & & \\
\hline 0 & WILD & 0 & 16,602 & 0 \\
\hline 1 & CAPTIVE & 0 & 0 & 0 \\
\hline
\end{tabular}


Table 5 (continued)

\begin{tabular}{|c|c|c|c|c|}
\hline Class index & Class name & Fisher's ratio & Abundance & Variance \\
\hline 577.5181274 & - & - & & \\
\hline 0 & WILD & 30.008172 & $10,626.5$ & 20.25 \\
\hline 1 & CAPTIVE & 21.272936 & $62,463.6071$ & $919,240,604.8$ \\
\hline 578.5205078 & - & - & & \\
\hline 0 & WILD & 64.658353 & 0 & 0 \\
\hline 1 & CAPTIVE & 51.946069 & $29,743.4783$ & $83,708,544.42$ \\
\hline 579.5328979 & - & - & & \\
\hline 0 & WILD & 72.060451 & $70,986.75$ & $446,919,288.2$ \\
\hline 1 & CAPTIVE & 117.405088 & $13,709.0909$ & $7,324,462.81$ \\
\hline 580.5358276 & - & - & & \\
\hline 0 & WILD & 41.523891 & $29,906.3333$ & $126,733,981.6$ \\
\hline 1 & CAPTIVE & 123.545929 & 12,100 & 0 \\
\hline 581.5288086 & - & - & & \\
\hline 0 & WILD & 791.590654 & 11,316 & 839,056 \\
\hline 1 & CAPTIVE & 998.821019 & 0 & 0 \\
\hline 589.4833984 & - & - & & \\
\hline 0 & WILD & 1023.670665 & 0 & 0 \\
\hline 1 & CAPTIVE & 1010.241181 & 11,100 & 40,000 \\
\hline 591.4968872 & - & - & & \\
\hline 0 & WILD & 86.350138 & 0 & 0 \\
\hline 1 & CAPTIVE & 64.326104 & $18,152.9412$ & $32,664,844.29$ \\
\hline 592.5021973 & - & - & & \\
\hline 0 & WILD & 501.388443 & 0 & 0 \\
\hline 1 & CAPTIVE & 451.247786 & 11,375 & 716,875 \\
\hline 593.5101929 & - & - & & \\
\hline 0 & WILD & 182.533883 & 0 & 0 \\
\hline 1 & CAPTIVE & 149.048477 & 13,570 & $5,666,100$ \\
\hline 593.5333252 & - & - & & \\
\hline 0 & WILD & 394.382685 & $15,093.3333$ & $5,326,838.889$ \\
\hline 1 & CAPTIVE & 624.886576 & 0 & 0 \\
\hline 601.5162964 & - & - & & \\
\hline 0 & WILD & 109.079565 & 0 & 0 \\
\hline 1 & CAPTIVE & 79.417804 & $13,342.8571$ & $15,239,591.84$ \\
\hline 603.5314941 & - & - & & \\
\hline 0 & WILD & 52.876154 & 0 & 0 \\
\hline 1 & CAPTIVE & 38.806967 & $36,491.1739$ & $228,252,278.8$ \\
\hline 604.5349731 & - & - & & \\
\hline 0 & WILD & 95.106533 & 0 & 0 \\
\hline 1 & CAPTIVE & 75.793148 & 18,800 & $23,674,117.65$ \\
\hline 605.5426025 & - & - & & \\
\hline 0 & WILD & 84.440844 & 0 & 0 \\
\hline 1 & CAPTIVE & 71.52418 & 18,415 & $18,131,275$ \\
\hline 608.5656128 & - & - & & \\
\hline 0 & WILD & 510.455258 & $13,364.6667$ & $1,930,598.222$ \\
\hline 1 & CAPTIVE & 655.013801 & 0 & 0 \\
\hline
\end{tabular}


Table 5 (continued)

\begin{tabular}{|c|c|c|c|c|}
\hline Class index & Class name & Fisher's ratio & Abundance & Variance \\
\hline 609.4887695 & - & - & & \\
\hline 0 & WILD & 0 & 0 & 0 \\
\hline 1 & CAPTIVE & 0 & 12,200 & 0 \\
\hline 612.5499268 & - & - & & \\
\hline 0 & WILD & 681.351434 & 0 & 0 \\
\hline 1 & CAPTIVE & 668.110166 & $10,633.3333$ & $82,222.22222$ \\
\hline 617.510376 & - & - & & \\
\hline 0 & WILD & 288.790034 & 0 & 0 \\
\hline 1 & CAPTIVE & 277.503659 & $10,571.4286$ & $393,469.3878$ \\
\hline 619.5269775 & - & - & & \\
\hline 0 & WILD & 247.653897 & 0 & 0 \\
\hline 1 & CAPTIVE & 228.050446 & 12,050 & $1,260,000$ \\
\hline 626.2260132 & - & - & & \\
\hline 0 & WILD & 0 & 15,830 & 0 \\
\hline 1 & CAPTIVE & 0 & 0 & 0 \\
\hline 642.4993286 & - & - & & \\
\hline 0 & WILD & 0 & 0 & 0 \\
\hline 1 & CAPTIVE & 0 & 11,600 & 0 \\
\hline 649.6848755 & - & - & & \\
\hline 0 & WILD & 0 & 18,533 & 0 \\
\hline 1 & CAPTIVE & 0 & 0 & 0 \\
\hline 656.5111084 & - & - & & \\
\hline 0 & WILD & 981.32276 & 0 & 0 \\
\hline 1 & CAPTIVE & 683.005018 & 11,850 & $1,562,500$ \\
\hline 663.4520264 & - & - & & \\
\hline 0 & WILD & 1.77635 & $59,474.5$ & $1,032,452,323$ \\
\hline 1 & CAPTIVE & 2.187012 & $46,699.6296$ & $601,173,474.3$ \\
\hline 664.4577026 & - & - & & \\
\hline 0 & WILD & 0.925652 & 29,827 & $286,433,890$ \\
\hline 1 & CAPTIVE & 1.433254 & $25,454.5455$ & $103,563,388.4$ \\
\hline 665.4603271 & - & - & & \\
\hline 0 & WILD & 203.172127 & 10,105 & 0 \\
\hline 1 & CAPTIVE & 56.667332 & 11,900 & $1,025,000$ \\
\hline 675.6990967 & - & - & & \\
\hline 0 & WILD & 0 & 13,127 & 0 \\
\hline 1 & CAPTIVE & 0 & 0 & 0 \\
\hline 677.7145996 & - & - & & \\
\hline 0 & WILD & 0 & 25,482 & 0 \\
\hline 1 & CAPTIVE & 0 & 0 & 0 \\
\hline 684.2030029 & - & - & & \\
\hline 0 & WILD & 58.018505 & 20,854 & $149,590,608.7$ \\
\hline 1 & CAPTIVE & 287.610803 & 0 & 0 \\
\hline 688.1956787 & - & - & & \\
\hline 0 & WILD & 0 & 13,513 & 0 \\
\hline 1 & CAPTIVE & 0 & 0 & 0 \\
\hline
\end{tabular}


Table 5 (continued)

\begin{tabular}{|c|c|c|c|c|}
\hline Class index & Class name & Fisher's ratio & Abundance & Variance \\
\hline 691.7000122 & - & - & & \\
\hline 0 & WILD & 0 & 13,127 & 0 \\
\hline 1 & CAPTIVE & 0 & 0 & 0 \\
\hline 698.255188 & - & - & & \\
\hline 0 & WILD & 494.667523 & 15,523 & $5,740,816$ \\
\hline 1 & CAPTIVE & 935.818658 & 0 & 0 \\
\hline 738.630188 & - & - & & \\
\hline 0 & WILD & 0 & 0 & 0 \\
\hline 1 & CAPTIVE & 0 & 10,000 & 0 \\
\hline 740.633728 & - & - & & \\
\hline 0 & WILD & 1019.796954 & 0 & 0 \\
\hline 1 & CAPTIVE & 969.360676 & 11,200 & 160,000 \\
\hline 766.6524048 & - & - & & \\
\hline 0 & WILD & 329.593048 & 0 & 0 \\
\hline 1 & CAPTIVE & 294.086201 & $10,916.6667$ & $1,091,388.889$ \\
\hline 824.7703247 & - & - & & \\
\hline 0 & WILD & 501.842599 & 23,094 & $12,355,225$ \\
\hline 1 & CAPTIVE & 938.074049 & 0 & 0 \\
\hline 825.7698975 & - & - & & \\
\hline 0 & WILD & 825.934481 & 14,197 & $1,079,521$ \\
\hline 1 & CAPTIVE & 1003.501123 & 0 & 0 \\
\hline 848.7681885 & - & - & & \\
\hline 0 & WILD & 0 & 0 & 0 \\
\hline 1 & CAPTIVE & 0 & 15,300 & 0 \\
\hline 850.7814941 & - & - & & \\
\hline 0 & WILD & 0 & 0 & 0 \\
\hline 1 & CAPTIVE & 0 & 14,100 & 0 \\
\hline 852.8024902 & - & - & & \\
\hline 0 & WILD & 937.491034 & 19,190 & 763,876 \\
\hline 1 & CAPTIVE & 1016.565328 & 0 & 0 \\
\hline 853.802002 & - & - & & \\
\hline 0 & WILD & 1016.982579 & 11,635 & 23,716 \\
\hline 1 & CAPTIVE & 1024.282225 & 0 & 0 \\
\hline 874.7836304 & - & - & & \\
\hline 0 & WILD & 0 & 0 & 0 \\
\hline 1 & CAPTIVE & 0 & 10,700 & 0 \\
\hline 876.7979126 & - & - & & \\
\hline 0 & WILD & 0 & 0 & 0 \\
\hline 1 & CAPTIVE & 0 & 17,300 & 0 \\
\hline 877.8029175 & - & - & & \\
\hline 0 & WILD & 0 & 0 & 0 \\
\hline 1 & CAPTIVE & 0 & 10,300 & 0 \\
\hline 880.8275146 & - & - & & \\
\hline 0 & WILD & 0 & 10,086 & 0 \\
\hline 1 & CAPTIVE & 0 & 0 & 0 \\
\hline
\end{tabular}


Acknowledgements Funding for this research was provided by players of People's Postcode Lottery, through a project collaboration with the NGO, TRAFFIC. We are grateful for the assistance of Eileen Westwig and the Oxford University Natural History Museum in sourcing and loaning of wild lion bone material. We also thank the South African National Biodiversity Institute (SANBI) and E. Pretorius for helping us to source captive-bred lion bone samples. This work would not have been possible without the general assistance of the South African Department of Environment, Forestry and Fisheries and we are grateful for the input of all concerned. In addition, we thank Markus Rusham for sharing his insights into the use of Mass Mountaineer software and Stephen Coals for his comments on the manuscript.

Author contributions P.C: conceptualization; analysis and investigation; writing (first draft); writing (review \& editing). A.L: conceptualization; supervision; writing (review \& editing). D.K: analysis and investigation; writing (review \& editing). V.L.W: sample collection; writing (review \& editing). D.W.M: supervision; writing (review \& editing). R.O: conceptualization; supervision; writing (review \& editing).

Funding Funding for this research was provided by players of People's Postcode Lottery, through a project collaboration with the NGO, TRAFFIC.

Data availability Summary data and sample identification numbers are included as appendices and access to full spectra data may be requested directly from the authors.

\section{Declarations}

Conflict of interest The authors declare that they have no conflict of interest.

Consent for publication All authors consent to publication.

Ethical approval Bone samples were transferred from South Africa to the UK under CITES scientific institution licence numbers: South Africa, ZA034 (National Zoological Gardens of South Africa); UK, GB031 (SASA).

Open Access This article is licensed under a Creative Commons Attribution 4.0 International License, which permits use, sharing, adaptation, distribution and reproduction in any medium or format, as long as you give appropriate credit to the original author(s) and the source, provide a link to the Creative Commons licence, and indicate if changes were made. The images or other third party material in this article are included in the article's Creative Commons licence, unless indicated otherwise in a credit line to the material. If material is not included in the article's Creative Commons licence and your intended use is not permitted by statutory regulation or exceeds the permitted use, you will need to obtain permission directly from the copyright holder. To view a copy of this licence, visit http://creativecommons.org/licenses/by/4.0/.

\section{References}

Ambrose SH (1991) Effects of diet, climate and physiology on nitrogen isotope abundances in terrestrial foodwebs. J Archaeol Sci 18(3):293-317

Bauer H, Chapron G, Nowell K, Henschel P, Funston P, Hunter LT, Packer C (2015) Lion (Panthera leo) populations are declining rapidly across Africa, except in intensively managed areas. Proc Natl Acad Sci USA 112(48):14894-14899

Bauer H, Packer C, Funston PF, Henschel P, Nowell K (2016) Panthera leo (errata version published in 2017). The IUCN Red List of Threatened Species 2016: e.T15951A115130419. https://doi.org/10. 2305/IUCN.UK.2016-3.RLTS.T15951A107265605.en. Accessed 14 Sept 2019

Borgers M (1980) Mechanism of action of antifungal drugs, with special reference to the imidazole derivatives. Rev Infect Dis 2(4):520-534

Brandis KJ, Meagher PJ, Tong LJ, Shaw M, Mazumder D, Gadd P, Ramp D (2018) Novel detection of provenance in the illegal wildlife trade using elemental data. Sci Rep 8(1):1-8

Broad S, Mulliken T, Roe D (2014) The nature and extent of legal and illegal trade in wildlife. The trade in wildlife. Routledge, London, pp 25-44

Bulte EH, Damania R (2005) An economic assessment of wildlife farming and conservation. Conserv Biol 19(4):1222-1233 
Cerling TE, Harris JM (1999) Carbon isotope fractionation between diet and bioapatite in ungulate mammals and implications for ecological and paleoecological studies. Oecologia 120(3):347-363

CITES (2016) Committee 1: Conservation of and the trade in the African Lion. CoP17 Com. 1. 29. https:// cites.org/sites/default/files/eng/cop/17/Com_I/E-CoP17-Com-I-29.pdf. Accessed 29 Apr 2020

Coals P, Burnham D, Loveridge A, Macdonald DW, Sas-Rolfes MT, Williams VL, Vucetich JA (2019) The ethics of human-animal relationships and public discourse: a case study of lions bred for their bones. Animals 9(2):52

Cody RB, Laramée JA, Durst HD (2005a) Versatile new ion source for the analysis of materials in open air under ambient conditions. Anal Chem 77(8):2297-2302

Cody RB, Laramée JA, Nilles JM, Durst HD (2005b) Direct analysis in real time (DART) mass spectrometry. JEOL News 40(1):8-12

Cody RB, Dane AJ, Dawson-Andoh B, Adedipe EO, Nkansah K (2012) Rapid classification of White Oak (Quercus alba) and Northern Red Oak (Quercus rubra) by using pyrolysis direct analysis in real time (DART) and time-of-flight mass spectrometry. J Anal Appl Pyrol 95:134-137

Dalton DL, Kotzé A, McEwing R, De Bruyn M, Mnisi C, Mwale M (2018) A tale of the traded cat: development of a rapid real-time PCR diagnostic test to distinguish between lion and tiger bone. Conserv Genet Resour 12:29-31

Damania R, Bulte EH (2007) The economics of wildlife farming and endangered species conservation. Ecol Econ 62(3-4):461-472

Davidson Z, Valeix M, Van Kesteren F, Loveridge AJ, Hunt JE, Murindagomo F, Macdonald DW (2013) Seasonal diet and prey preference of the African lion in a waterhole-driven semi-arid savanna. PLoS ONE 8(2):e55182

DEA (2017) Lion export quota for 2017 communicated to the CITES Secretariat in line with CITES requirements. https://www.environment.gov.za/mediarelease/lionexportquota_communicatedtocitess ecretariat. Accessed 29 Apr 2020

De Telegraaf (2019) Honderden kilo's leeuwenbotten onderschept. https://www.telegraaf.nl/nieuws/14924 87166/honderden-kilo-s-leeuwenbotten-onderschept. Accessed 3 Oct 2019

Dutton AJ, Gratwicke B, Hepburn C, Herrera EA, Macdonald DW (2013) Tackling unsustainable wildlife trade. Key Top Conserv Biol 2(5):74-91

EAGLE (2017) The EAGLE Network Annual Report 2017. EAGLE Network. http://www.eagle-enfor cement.org/data/files/eagle-network-annual-report-2017.pdf. Accessed 17 July 2019

EAGLE (2018) The EAGLE Network Annual Report 2018. EAGLE Network. http://www.eagle-enfor cement.org/data/files/eagle-network-annual-report-2018.pdf. Accessed 17 July 2019

EIA (2017) The lion's share: South Africa's trade exacerbates demand for tiger parts and derivatives. The Environmental Investigation Agency. https://eia-international.org/wp-content/uploads/The-LionsShare-FINAL-1.pdf. Accessed 17 Jan 2020

EMS (2018) The extinction business: South Africa's 'Lion' Bone Trade. EMS \& Ban Animal Trading. https://emsfoundation.org.za/wp-content/uploads/THE-EXTINCTION-BUSINESS-South-Africaslion-bone-trade.pdf. Accessed 29 April 2020

Espinoza EO, Lancaster CA, Kreitals NM, Hata M, Cody RB, Blanchette RA (2014) Distinguishing wild from cultivated agarwood (Aquilaria spp.) using direct analysis in real time and time of-flight mass spectrometry. Rapid Commun Mass Spectrom 28(3):281-289

Everatt KT, Kokes R, Pereira CL (2019) Evidence of a further emerging threat to lion conservation; targeted poaching for body parts. Biodivers Conserv 28(14):4099-4114

Fischer C (2004) The complex interactions of markets for endangered species products. J Environ Econ Manag 48(2):926-953

Gore ML, Braszak P, Brown J, Cassey P, Duffy R, Fisher J, Machalaba C (2019) Transnational environmental crime threatens sustainable development. Nat Sustain 2(9):784-786

Grange AH, Sovocool GW (2011) Detection of illicit drugs on surfaces using direct analysis in real time (DART) time-of-flight mass spectrometry. Rapid Commun Mass Spectrom 25(9):1271-1281

Hayward MW, Kerley GI (2005) Prey preferences of the lion (Panthera leo). J Zool 267(3):309-322

He Y, Wang J, Wang M, Zhang J (2018) Discrimination of wild and domestic deer musk using isotope ratio mass spectrometry. J Mass Spectrom 53(11):1078-1085

Hemley G (1994) International wildlife trade: a CITES sourcebook. Island Press

Hinsley A, King E, Sinovas P (2016) Tackling illegal wildlife trade by improving traceability: a case study of the potential for stable isotope analysis. The geography of environmental crime. Palgrave Macmillan, London, pp 91-119

Hogg CJ, Dennison S, Frankham GJ, Hinds M, Johnson RN (2018) Stopping the spin cycle: genetics and bio-banking as a tool for addressing the laundering of illegally caught wildlife as 'captive-bred.' Conserv Genet Resour 10(2):237-246 
Hutchinson A, Roberts DL (2020) Differentiating captive and wild African lion (Panthera leo) populations in South Africa, using stable carbon and nitrogen isotope analysis. Biodivers Conserv 29:2255-2273

Jimenez-Bustamante D, Rentería LPD (2018) Laundering of Illegal Wild Fauna in Mexico: case study of a pair of desert monitors Varanus griseus griseus (Daudin, 1803). Green crime in Mexico. Palgrave Macmillan, Cham, pp 127-136

Juarez CA (2008) Strontium and geolocation, the pathway to identification for deceased undocumented Mexican border-crossers: a preliminary report. J Forensic Sci 53(1):46-49

Katzenberg MA (2008) Stable isotope analysis: a tool for studying past diet, demography, and life history. Biol Anthropol Hum Skelet 2:413-441

Kays R, Feranec RS (2011) Using stable carbon isotopes to distinguish wild from captive wolves. Northeast Nat 18(3):253-264

Kharb R, Sharma PC, Yar MS (2011) Pharmacological significance of triazole scaffold. J Enzyme Inhib Med Chem 26(1):1-21

Kim HJ, Jee EH, Ahn KS, Choi HS, Jang YP (2010) Identification of marker compounds in herbal drugs on TLC with DART-MS. Arch Pharmacal Res 33(9):1355-1359

Lancaster C, Espinoza E (2012) Analysis of select Dalbergia and trade timber using direct analysis in real time and time-of-flight mass spectrometry for CITES enforcement. Rapid Commun Mass Spectrom 26(9):1147-1156

Lyons JA, Natusch DJ (2011) Wildlife laundering through breeding farms: illegal harvest, population declines and a means of regulating the trade of green pythons (Morelia viridis) from Indonesia. Biol Conserv 144(12):3073-3081

Macdonald DW, Laurenson MK (2006) Infectious disease: inextricable linkages between human and ecosystem health. Biol Conserv 131(2):143

Mass Mountaineer (2018) Mass Mountaineer Guide. Version 5.0. Diablo Analytical. https://diabloanalytical.com/ms-software/mass-mountaineer/

Masters A, Ogden R, Wetton JH, Dawnay N (2019) Defining end user requirements for a field-based molecular detection system for wildlife forensic investigations. Forensic Sci Int 301:231-239

Meier-Augenstein W (2017) Stable isotope forensics: methods and forensic applications of stable isotope analysis. Wiley

Miller SM, Harper CK, Bloomer P, Hofmeyr J, Funston PJ (2014) Evaluation of microsatellite markers for populations studies and forensic identification of African lions (Panthera leo). J Hered 105(6):856-866

Morrison J, Watts G, Hobbs G, Dawnay N (2018) Field-based detection of biological samples for forensic analysis: established techniques, novel tools, and future innovations. Forensic Sci Int 285:147-160

Nilles JM, Connell TR, Stokes ST, Dupont Durst H (2010) Explosives detection using direct analysis in real time (DART) mass spectrometry. Propellants Explos Pyrotech 35(5):446-451

Ogden R, Dawnay N, McEwing R (2009) Wildlife DNA forensics—bridging the gap between conservation genetics and law enforcement. Endang Species Res 9(3):179-195

Ogden R, Mailley J (2016) A review of wildlife forensic science and laboratory capacity to support the implementation and enforcement of CITES. In: Review commissioned by the Secretariat of the Convention on International Trade in Endangered Species of Wild Fauna and Flora and review undertaken by the United Nations Office on Drugs and Crime (Vol. 37)

Outhwaite W (2018) The legal and illegal trade in African lions; a study in support of decision 17. TRAFFIC, Cambridge, p 241

Pavlovich MJ, Musselman B, Hall AB (2018) Direct analysis in real time-mass spectrometry (DART-MS) in forensic and security applications. Mass Spectrom Rev 37(2):171-187

Price ER, McClure PJ, Jacobs RL, Espinoza EO (2018) Identification of rhinoceros keratin using direct analysis in real time time-of-flight mass spectrometry and multivariate statistical analysis. Rapid Commun Mass Spectrom 32(24):2106-2112

Republic of South Africa. In the Matter between National Council of The Society for Prevention of Cruelty to Animals and Minister for Environmental Affairs, Director-General Department of Environmental Affairs, South African Predator Association. Case number: 86515/2017. 2019. https://nspca.co.za/wpcontent/uploads/2019/08/Lion-Bone-judgment-1.pdf. Accessed 12 Aug 2019

Rosen GE, Smith KF (2010) Summarizing the evidence on the international trade in illegal wildlife. EcoHealth 7(1):24-32

Ross JH, Krieger RI (1980) Synthesis and properties of paraquat (methyl viologen) and other herbicidal alkyl homologs. J Agric Food Chem 28(5):1026-1031

Shimizu S, Watanabe N, Kataoka T, Shoji T, Abe N, Morishita S, Ichimura H (2000) Pyridine and pyridine derivatives Ullmann's encyclopedia of industrial chemistry. Wiley, New York

Sisco E, Forbes TP, Staymates ME, Gillen G (2016) Rapid analysis of trace drugs and metabolites using a thermal desorption DART-MS configuration. Anal Methods 8(35):6494-6499 
Smoluch M, Mielczarek P, Silberring J (2016) Plasma-based ambient ionization mass spectrometry in bioanalytical sciences. Mass Spectrom Rev 35(1):22-34

Souza C (2010) Kernel Principal Component Analysis in C\#. http://crsouza.com/2010/01/19/kernel-princ ipal-component-analysis-in-c/. Accessed 21 Feb 2020

Sugiyama N, Fash WL, France CA (2018) Jaguar and puma captivity and trade among the Maya: stable isotope data from Copan, Honduras. PLoS ONE 13(9):e0202958

Tranquilli WJ, Thurmon JC, Grimm KA (eds) (2013) Lumb and Jones' veterinary anesthesia and analgesia. Wiley, New York

UN (2018) The state of knowledge of crimes that have serious impacts on the environment. United Nations Environment Programme. https://wedocs.unep.org/bitstream/handle/20.500.11822/25713/knowledge_ crime_envImpacts.pdf?sequence=1\&isAllowed=y Accessed 6 Jan 2020

van Uhm D (2018) Wildlife and laundering. In: Spapens T, White R, Van Uhm D, Huisman W (eds) Green crimes and dirty money. Routledge, London

Volpato G, Fontefrancesco MF, Gruppuso P, Zocchi DM, Pieroni A (2020) Baby pangolins on my plate: possible lessons to learn from the COVID-19 pandemic. Springer, Berlin

Warchol GL (2004) The transnational illegal wildlife trade. Crim Justice Stud 17(1):57-73

Wells JM, Roth MJ, Keil AD, Grossenbacher JW, Justes DR, Patterson GE, Barket DJ (2008) Implementation of DART and DESI ionization on a fieldable mass spectrometer. J Am Soc Mass Spectrom 19(10):1419-1424

Williams VL, Newton DJ, Loveridge AJ, Macdonald DW (2015) Bones of contention: an assessment of the South African trade in African lion Panthera leo bones and other body parts. TRAFFIC \& WildCRU, Cambridge, Oxford

Williams VL, Loveridge AJ, Newton DJ, Macdonald DW (2017a) A roaring trade? The legal trade in Panthera leo bones from Africa to East-Southeast Asia. PLoS ONE 12(10):e0185996

Williams VL, Loveridge AJ, Newton DJ, Macdonald DW (2017b) Questionnaire survey of the pan-African trade in lion body parts. PLoS ONE 12(10):e0187060

Williams VL, 't Sas-Rolfes MJ (2019) Born captive: a survey of the lion breeding, keeping and hunting industries in South Africa. PLoS ONE 14(5):e0217409

Williams VL, Coals PG, de Bruyn M, Naude VN, Dalton DL, Kotzé A (2021) Monitoring compliance of CITES lion bone exports from South Africa. PLoS ONE 16(4):e0249306

Zhu M, Zhang H, Humphreys WG (2011) Drug metabolite profiling and identification by high-resolution mass spectrometry. J Biol Chem 286(29):25419-25425

Zimmerman ME (2003) The black market for wildlife: Combating transnational organized crime in the illegal wildlife trade. Vand J Transnat'1 L 36:1657

Publisher's Note Springer Nature remains neutral with regard to jurisdictional claims in published maps and institutional affiliations.

\section{Authors and Affiliations}

\section{Peter Coals ${ }^{1,2}$ - Andrew Loveridge ${ }^{1}$. Dominic Kurian ${ }^{3} \cdot$ Vivienne L. Williams $^{1,2}$. David W. Macdonald ${ }^{1} \cdot$ Rob Ogden ${ }^{3,4}$}

1 Wildife Conservation Research Unit, Recanati-Kaplan Centre, Department of Zoology, University of Oxford, Tubney OX13 5QL, UK

2 School of Animal, Plant \& Environmental Science, University of the Witwatersrand, Johannesburg 2000, South Africa

3 Royal (Dick) School of Veterinary Studies and The Roslin Institute, Easter Bush Campus, University of Edinburgh, Edinburgh EH25 9RG, UK

4 TRACE Wildlife Forensics Network, Edinburgh EH12 6LE, UK 